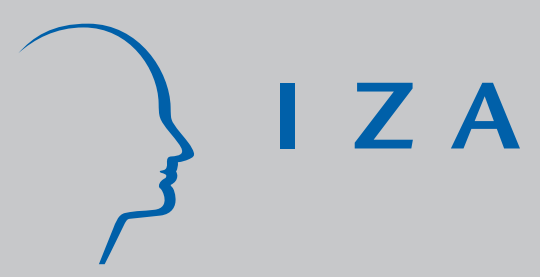

IZA DP No. 1288

Women's Hours of Market Work in Germany: The Role of Parental Leave

Monika Merz

September 2004 


\title{
Women's Hours of Market Work in Germany: The Role of Parental Leave
}

\author{
Monika Merz \\ University of Bonn \\ and IZA Bonn
}

Discussion Paper No. 1288
September 2004

IZA

P.O. Box 7240

53072 Bonn

Germany

Phone: +49-228-3894-0

Fax: +49-228-3894-180

Email: iza@iza.org

\begin{abstract}
Any opinions expressed here are those of the author(s) and not those of the institute. Research disseminated by IZA may include views on policy, but the institute itself takes no institutional policy positions.
\end{abstract}

The Institute for the Study of Labor (IZA) in Bonn is a local and virtual international research center and a place of communication between science, politics and business. IZA is an independent nonprofit company supported by Deutsche Post World Net. The center is associated with the University of Bonn and offers a stimulating research environment through its research networks, research support, and visitors and doctoral programs. IZA engages in (i) original and internationally competitive research in all fields of labor economics, (ii) development of policy concepts, and (iii) dissemination of research results and concepts to the interested public.

IZA Discussion Papers often represent preliminary work and are circulated to encourage discussion. Citation of such a paper should account for its provisional character. A revised version may be available directly from the author. 


\section{ABSTRACT \\ Women's Hours of Market Work in Germany: The Role of Parental Leave*}

This paper investigates trends and changes in the structural composition of women's weekly market hours worked in former West-Germany using aggregate time-series data from the German micro census from 1957 until 2002. Aggregate weekly hours worked per workingage woman are decomposed into hours worked per employee - the intensive margin of adjustment - and the employment-to-population (EP-) ratio - the extensive margin. The decomposition is performed by women's marital status, their age, and whether or not young children are present. The main results are that since the mid 1970s, the EP-ratio has steadily risen among female employees of all marital statuses whereas the weekly hours worked per female employee have declined. These changes have been the most distinct among married women with young children. The paper attributes much of the observed changes for married women to institutional modifications in the federal legislation governing parental leave which have occurred since 1986.

JEL Classification: J13, J22

Keywords: female labor supply, extensive and intensive margin of adjustment, parental leave and benefit policy

Monika Merz

Department of Economics

University of Bonn

Adenauerallee 24-42

53113 Bonn

Germany

Email: mmerz@uni-bonn.de

\footnotetext{
* Prepared for presentation at the ECB/CEPR conference on "What explains the pattern of labour supply in Europe?" Frankfurt a.M., June 2003. I thank Chinhui Juhn, Guy Laroque and seminar participants at Arizona State University and IGIER at Università Bocconi for useful comments. Financial support from the German Science Foundation (Deutsche Forschungsgemeinschaft) is gratefully acknowledged. This project was started while I visited RUESG at the University of Helsinki. I thank Erkki Koskela and Seppo Honkapohja for their generous hospitality. Markus Demary provided able research assistance. All errors and omissions are my own.
} 


\section{INTRODUCTION}

The literature on female labor supply often departs from the presumption that in most industrialized countries women's market hours worked have steadily risen since the early 1970s. A commonly quoted example is the experience of married women in the U.S. Their average hours worked have risen by over sixty percent during the last three decades (McGrattan and Rogerson 1998, 2004). For married women with children this rise has been even more extreme. The secular increase in women's hours worked has become the subject of a growing body of literature which uses dynamic economic models in an effort to explain the driving forces underlying this trend (see, e.g., Olivetti 2001, or Jones et al. 2003). Often quoted exceptions to the above-mentioned empirical observations are Germany, Italy and Spain where women's total market hours worked have remained constant at best. Given that fertility in these countries has declined over the past thirty years and reached the bottom of the distribution in Europe, the observations on Germany, Italy and Spain are considered a puzzle, because at first glance it is hard to perceive why women who have few children do not participate more actively in the labor market. At second glance, there are likely candidates that may help explain the observed differences, such as child care availability, the income tax system, parental leave policies, the legal length of the workweek, or the availability of parttime jobs.

In this paper we explore the development of women's involvement in the German labor market since the late 1950s. We pursue two goals. Firstly, we document the trends of market hours worked of different groups of women. Contrary to most of the existing literature, we not only study women's employment-to-population ratio, but also their weekly hours worked in the market. We provide compelling evidence that exclusively focusing on the EP-ratio, or labor force participation in an effort to understand women's labor market involvement can be misleading. Towards this end, we decompose women's market hours worked into hours worked per female employee-the intensive margin - and the employment-to-population (EP-) ratio - the extensive margin. Secondly, we investigate the link between the observed deline in women's weekly hours and three major changes in the federal regulation governing parental leave which have taken place since the late 1970s. To do so, we illustrate the changes in the actual weekly hours of married females with children below the age of ten - the group for whom average weekly hours and the employment rate have changed during the period of observation — and contrast them to the respective changes in the control group, i.e., married females without young children. We use micro census data 
from the German Federal Statistical Office (Statistisches Bundesamt). At a highly aggregated level, these data are available from 1957 through 2002 for former West-Germany. They allow us to study long-term trends of the variables of interest, and also structural changes.

Our findings suggest that the near constancy in aggregate series of hours worked per working-age woman that has been observed since the late 1950s hides a vast set of different trends in the intensive and extensive margin of women's involvement in the German labor market. The employment-to-population ratio has steadily risen among female employees of all marital statuses, the exception being single female employees; for them, the employment rate has remained roughly constant. The general rise occurred steadily across consecutive cohorts. The rise in the female employment ratio has been accompanied by a notable decline in women's weekly hours worked. We identify married women with young children as the group of female employees for whom the changes in the intensive and extensive margin have been the most severe. We attribute much of these changes to the federal parental leave policy in the country which, compared to international standards, is considered very generous. ${ }^{2}$ The federal legislation governing parental leave underwent major modifications in 1986, 1992 and 2001. We use those institutional changes in order to assess the impact that parental leave policy has had on women's labor market involvement in Germany.

The paper proceeds as follows. Section two presents the data underlying the study. Section three sets the scene for a taking a closer look at women's hours worked in the market by studying long-term trends of the aggregate series that are decomposed by gender, age and marital status. Section four takes a closer look at changes in the federal legislation governing parental leave and studies the impact of these changes on married women's labor market behavior. Section five concludes.

\section{THE DATA}

All data underlying our study originate from the micro census of the German Federal Statistical Office. The micro census is the official statistic of the population and the labor force in Germany; it has been available since 1957 for the former West-Germany and since 1991 for the former East-Germany. ${ }^{3}$ The most recent results currently available are for 2002. In terms of data collection method applied, it is comparable to the Current Population Survey of the U.S. Data are collected by annual interviews of one percent of all households that are

\footnotetext{
${ }^{2}$ See OECD (1995).

${ }^{3}$ The former West-Germany comprises the states Bremen, Hamburg, Schleswig-Holstein, Northrhine-Westfalia, Hessia, Lower Saxony, Rhineland-Palatine, Baden-Wuerttemberg, Bavaria, the Saarland and West-Berlin.
} 
randomly drawn. In every year, about 370,000 households with 820,000 individuals participate in the interviews. Out of these, about 70,000 households with 160,000 individuals primarily live in the former East-Germany. Interviews take place between April and July. They are typically staged with the head of a chosen household who is asked to respond to questions relating to the various household members. Hence, the data are gathered through a household's self-reporting. The response rate regularly reaches at least 97 percent. Responses to questions relating to labor market activities relate to an ex ante chosen week of the year, the so-called reference week. That particular week has varied over time - it currently is the last week of April in which there are no public holidays. A quarter of all participating households are rotated each year, so that a chosen household participates in the sample on average for four years. ${ }^{4}$ Questions relating to the number of weekly hours worked when employed cover actual as well as normal hours worked during the reference week. In case these two figures deviate from each other, the interviewees give reasons for the deviation such as overtime, vacation, illness, flexible work hours, or other reasons, including parental leave.

The micro census results that have been available since 1957 are based on individual, regional or time aggregation. Individual data are aggregated based on characteristics such as gender, age, marital status, or sector of employment. The time-series have the advantage of consistently reporting the variables of interest over forty-five years for the former WestGermany. They obviously suffer from the fact that they are not available at a degree of disaggregation that currently is of interest to many researchers.

This deficiency has led the German Federal Statistical Office to make excerpts of the original micro-level data - so-called scientific use files - available to academic institutions. A scientific use file contains randomly drawn seventy percent of those households that participate in the micro census of the respective year. In order to render compatibility with the micro census data, the relevant entries in the sub-sample are multiplied by the factor 10/7. Scientific use files are available for 1989, 1991 1993, 1995, 1996, 1997 and 2000. The micro level data provide detailed information on an individuals' gender, age, marital status, educational attainment, whether or not children in various age categories are present, and also on individuals' labor market status. If applicable, the data also capture the economic situation of a person's partner. For those individuals who are employed, the data contain information on the actual number of weekly hours worked, and whether their job is full-time or part-time.

\footnotetext{
${ }^{4}$ There may be a source of systematic misreporting, simply because the time of the interview often does not coincide with the point in time for which the interviewee provides the information. However, whether or not the data actually suffer from such a mistake has not yet been analyzed.
} 
Our empirical work is based on the aggregate time-series of the micro census covering the period from 1957 through 2002. We use the aggregate time-series in order to illustrate trends in the evolution of gender-specific labor force participation rates, or weekly hours worked per employee. Most importantly, we can divide market hours worked for each of these group-specific characteristics into the employment rate (extensive margin) and hours worked per employee (intensive margin), thereby searching for empirical regularities. We restrict our analysis to individuals and households who reside in the former West-Germany, primarily because our analysis requires consistent data over a rather long time-period. Naturally, such data are more readily available for former West-Germany than for the former East.

A comment on the informational content of the aggregate time-series underlying this paper is in place. The composition of the female population in former West-Germany has undergone major changes since the official micro census was started in 1957. Those changes are mostly due to three main waves of immigration. Starting in the 1970s so-called guestworkers from southern European countries and Turkey came to Germany to work. Many of those guest-workers and their families settled there permanently. Since the mid 1980s, many German descendents from Russia have immigrated to Germany. Lastly, German unification has led to much migration from former East-Germany into the Western states. Since data on West-Germany cover all those who reside in the former west, they include migrants and immigrants.

\section{TRENDS IN HOURS OF MARKET WORK}

Macroeconomists commonly use the total number of hours worked in the market as measure of labor input in the production of goods and services. This measure is typically reported in relation to the working age population. In Germany, where retirement at the age of 65 is mandatory in the public sector and common practice in all other sectors, the working age population covers all individuals who are between 15 and 64 years old. However, for the sake of comparing our results to those of related studies, we use as working age population all individuals who are at least 15 years old. Figure 1a depicts the ratio of total weekly hours worked to persons of working age together with the pendant for men and women. All three series declined markedly between 1957 and the mid 1970s. Thereafter, the measure for men continued to decline — albeit at a reduced pace—, whereas the measure for women remained constant. 
Although an important measure of the economy's total labor input, the aggregate series on hours worked hide much of the dynamics associated with their underlying components. To be specific, total hours worked per person (H/Pop) can be decomposed into total hours worked per employee $(H / E)$ - the intensive margin — and the extensive margin, employment-to-population $(E / P o p)$ :

$$
\left(\frac{H}{P o p}\right)_{i}=\left(\frac{H}{E}\right)_{i} \times\left(\frac{E}{P o p}\right)_{i} \quad i \in\{w, m, s\}
$$

where the index $i$ represents women $w$, men $m$, or the sum of the two $s$. We argue that in the case of Germany, studying hours worked per employee as measure for the intensive margin of adjustment is much more informative and appropriate than simply distinguishing between part-time and full-time work. That's because the exact classification of a particular job depends on the normal hours worked, and normal hours vary by sector. For example, a person working thirty-five hours a week is classified as part-time worker in a sector where the normal work week consists of thirty-eight hours. However, that same person would be classified as full-time worker if she worked in a sector where the normal work week consist of thirty-five hours. To avoid this ambiguity, we simply look at actual weekly hours worked.

The intensive and the extensive component each have undergone remarkable changes. Weekly hours worked per employee have declined for both men and women. As figure $1 \mathrm{~b}$ shows, this decline has been much more drastic for women than for men. Between the late 1950s and the mid 1960s — a time that has become known as post World War II Wirtschaftswunder in Germany_, male and female employees each worked well over 45 hours per week. During the following four decades, women on average reduced their weekly hours worked to less than 30 , while men reduced theirs to effectively 40 . The reduction in weekly hours worked was a continuous process which was accelerated in the 1980s. Two factors mainly contributed to this development. Firstly, starting in the mid 1980s, the length of the workweek was gradually reduced across most sectors. In 1985, for example, the metal industry negotiated an agreement to switch from 40 to 38.5 hours per week. In 1993, the number of weekly hours worked was further reduced to 36 . Similar agreements were adopted in other sectors. The reduction in the workweek came along with the possibility for firms to negotiate longer or shorter hours per week with a small fraction of their work force. Secondly, in 1979, the country's first law on parental leave became effective, enabling employed women who had given birth to take a leave from their job following maternity leave. This leave policy 
underwent various amendments which became effective in 1986, 1992 and 2001, respectively. The launch of the new policy was accompanied by a steady increase in the number of parttime jobs that have been occupied by women much more than by men. Taken together, these changes accelerated the decline in weekly hours worked per employee.

Theoretically at least the decomposition of total hours worked per person as summarized in equation (1) can be arbitrarily refined not just according to gender, but according to any other individual characteristic. In practice, the degree of refinement is limited by data availability. The aggregate series from the micro census allow us to decompose total weekly hours worked by gender and marital status, but not any further. At this level of disaggregation, the data have been available since 1975 for women and since 1990 for men. Decomposing the aggregate hours series by gender and marital status helps shed light on key differences in the labor market behavior of women and men. Data availability lets us consider an individual's marital status to be one of the following three states: single, married, widowed or divorced. A distinction between widowed or divorced is not possible at the aggregate data level.

\subsection{WOMEN's HOURS OF MARKET WORK}

Figure 2a suggests that the constancy in all women's weekly hours worked per person is related to the fact that this measure has remained constant for married women without young children, and that the decline in the measure for single women has been offset by the increase in the measure for married women with young children, and for widowed or divorced women. ${ }^{5}$ As far as the intensive margin of adjustment is concerned, single wome $\mathrm{n}$ have always worked more hours per week than widowed or divorced women whose weekly hours, in turn, have typically exceeded those of married women. In spite of these differences in levels, all three groups of female employees have reduced their number of hours worked per week to a comparable extent. These trends are summarized in figure $2 b$.

Married female employees with children below the age of ten have undergone the most severe reduction in weekly hours worked. As depicted by the solid line in figure $2 b$, this group of employees cut its weekly hours by close to forty-five percent between 1975 and 2000. The observed reduction gained momentum in the late 1970s and again around 1986 and 1992 - three points in time which coincide with major modifications in the federal legislation

\footnotetext{
${ }^{5}$ Between 1970 and 2000, the share of single women in the female population declined from 37 to 34 percent, while the share of divorced women rose from 2.2 to 5.4 percent.
} 
governing parental leave. We will focus on this group in particular when trying to assess the quantitative implications that changes in the parental leave policy have had on women's labor market involvement.

The development of women's employment-to-population ratio between 1975 and 2000 for the four groups considered is summarized in figure 2c. With the exception of single women for whom the employment rate has remained roughly constant, this ratio has increased. The rise has been the most distinct for married women with young children. Remarkably, theirs was the only rate to decline between the late 1970s and 1985; it has doubled since then and surpassed the ratio of single women. In 2000, the employment rate of married women with young children reached over 60 percent; it was the largest rate of all groups considered.

Figure 3 illustrates the life-cycle profile of women's employment-to-population ratio for particular cohorts in different years when women of all marital statuses are grouped together. ${ }^{6}$ This figure nicely illustrates how employment has changed from older to younger cohorts of women. Older women cohorts tended to be employed less at every stage in their life, and they more frequently tended not to work around the age when many of them had children. Younger cohorts, on the other hand, are employed less often at a younger and an older age, indicating an increased level of education as well as a reduced retirement age. They withdraw less frequently during their childbearing years which is the main reason why the traditional bi-modal shape of women's life-cycle employment has become hump-shaped for the youngest cohorts considered.

The prima facie evidence suggests that younger female cohorts' employment-topopulation ratio much more closely resembles that of men than did the EP-ratio of older female cohorts. However, this latter statement is subject to a major caveat. Since 1992, employed women who had a child can take parental leave up to three years after the child's birth (see section 4 for details). This generous parental leave policy has become very popular among younger female employees, leading to a steadily growing fraction of them who actually take such a leave if they have a child. It is important to note that following ILO convention, in Germany like in most European countries, the official statistics treat women on parental leave as employed, even though many of them do not work in the market at all during that time. One can argue that employees should be treated as not employed while being on parental leave and working zero hours. That, of course, would imply that women's employment pattern over their life-cycle has changed less drastically than figure 3 suggests. 
We recompute the series on hours worked per employee and the EP-ratio for the different groups of women considered counting only those as employed who work non-zero weekly hours. In figures $3 \mathrm{a}$ and $3 \mathrm{~b}$, we illustrate the conventional and the modified series for married women with young children for whom the discrepancy between the two types of measures is most notable. For each series considered, the conventional and the modified measure start diverging in the mid 1980s indicating that an increasing number of married employees with young children effectively work zero hours in the market.

The extent of the change in women's labor market involvement that has occurred since the late 1950s becomes all the more evident if it is contrasted to that of men. Men's employment-to-population ratio has remained roughly constant over the past 25 years. This ratio has also remained constant over different birth cohorts; younger cohorts have slightly reduced their employment ratio, but their overall involvement remains high. Single men have increased their EP-ratio while married men have decreased theirs, leaving the average employment-to-population ratio for men unaffected. A similar picture emerges when looking at weekly hours worked. This measure has only slightly decreased from 42 hours to ca. 40 hours per week since 1975, and the decrease has been born proportionately by men of different marital statuses.

\section{The Role of Parental Leave and Benefits}

There are several indications in the data that the introduction and subsequent modifications of the federal parental leave and benefit legislation in Germany have contributed to the observed changes in the labor market involvement of women with young children. In order to quantitatively assess this link, we first provide an overview of the timing and the extent of the institutional changes that occurred and then carefully study the data.

\subsection{SOME InSTITUTIONAL DETAILS}

Parental leave and benefit policies are closely tied to maternity leave and benefit policies. Maternity leave and the associated cash benefit typically is reserved to new mothers. When the father and the mother can share equally- that is, when either parent is eligible- the benefit

\footnotetext{
${ }^{6}$ The data for 1950 originate from the census which was conducted on September 13, 1950. They do not cover
} 
is termed parental leave. Both types of policies typically specify as key variables (1) the beneficiary, (2) the maximal possible duration of the job-protected leave period and (3) the period during which cash benefits can be received. The policies also specify the (4) size of and prerequisites for receiving those cash benefits, and (5) the extent to which individuals on leave can take up market work.

Germany has the longest tradition of maternity leave legislation among European countries dating back to the Bismarck era with its social insurance program ${ }^{7}$ The German Imperial Industrial Code of 1891 as part of this social program set maximum work hours and prohibited the employment of women within four weeks of childbirth. Amendments to the code in 1903 and 1911 increased the leave period to six weeks and supplied women with paid time off work in the two weeks before delivery. These early benefit policies subsequently were extended and improved to include job-protection and full salary support during the entire leave period. They culminated in the adoption of the law on maternity leave (Mutterschutzgesetz) which was passed in 1952. In 1968, female employees who expected a child enjoyed forteen weeks of mandatory maternity leave, six weeks of which had to be taken prior to delivery. During those fourteen weeks, a sickness insurance benefit is paid by the social security system at a flat rate equal to about the average salary for women workers, and employers are required to supplement this benefit to cover the woman's full salary.

Starting in January 1979, female employees on maternity leave could opt to take an additional four months of leave immediately following maternity leave. While on this extended leave, they received a monthly payment which depended on the average salary received during the three months preceding maternity leave. Women could not be dismissed and had the right to return to their employer, albeit not to their previous job. Although this leave policy can be viewed as an early form of parental leave, effectively it was nothing but an extension of maternity leave.

In January 1986, the first federal law on governmental transfer payments to new parents became effective (Bundeserziehungsgeldgesetz BerzGG). According to this law, any new parent working at most fifteen hours per week was entitled to receive a benefit (Erziehungsgeld) from the federal government, regardless of his or her previous labor market status. This benefit was tax-exempt. It equaled $600 \mathrm{DM}$ for the first six months. Starting from the seventh month, it was means-tested and paid for at most one year. The transfer payment

\footnotetext{
the Saarland and West-Berlin.

${ }^{7}$ For details on early maternity leave policies in Germany see Frank and Lipner (1988).
} 
has explicitly been aimed at providing a financial incentive for new parents to raise their children themselves at home. ${ }^{8}$

The same law also regulated the maximal possible duration of parental leave. Married mothers and fathers and unmarried mothers with an infant were entitled to an additional eight months of parental leave following the mother's maternity leave. This maximal leave duration was extended to twelve months in 1987, to fifteen months in 1989, and to eighteen months in 1990. Until the end of 1991, only those parents could opt to take the leave who were entitled to receive the government's parental cash benefit. Starting in 1992, eligible parents could take parental leave up to three years after the birth of their child. If married, a child's parents could decide on how to split up the parental leave time between each other. The possibility to take parental leave was disentangled from the eligibility to receive parental benefits for raising the child. Since 1993, eligible parents can receive those benefits for at most twenty-four months.

Another modification of the BerzGG became effective in January 2001. Employed mothers and their male partners - regardless of whether or not they are married - are entitled to take parental leave up to three years after the birth of their child. In fact, up to a third of this leave can be taken until the child turns eight years old, if the employer agrees. Married parents with an annual income of at least 100,000 DM (=51,130€) and all other parents with an annual income of at least 75,000 DM (=38,350 €) are excluded from receiving a parental benefit; all eligible parents can choose between receiving a monthly transfer of $600 \mathrm{DM}$ $(=307 €)$ for at most two years, or $900 \mathrm{DM}(=460 €)$ for at most one year.

Parental leave has been compatible with part-time work. Between 1986 and the end of 1988, a mother or a father on parental leave could work up to fifteen hours per week. Between 1989 and late 2000, they could work up to nineteen hours per week. Since 2001, individuals on parental leave can work up to thirty hours per week in the market.

In what follows, we document the impact that these legal changes have had on the extent to which employed females take parental leave, and on their market hours worked.

\subsection{EMPIRICAL EVIDENCE}

Assessing the quantitative importance of parental leave in former West-Germany is difficult, because direct evidence from aggregate time-series data is available for the period from 1987

\footnotetext{
${ }^{8}$ A married couple received the transfer payment as long as their annual net family income didn't exceed 29.400 DM. For a single parent, this income limit equaled 23.700 DM per year. Each additional child increased the upper limit by 4.200 DM.
} 
through 1991 only. During that time, receiving the parental benefit was a prerequisite for being eligible to take parental leave. The German Federal Statistical Office in its Statistical Yearbook (Statistisches Jahrbuch) reports the socio-economic profile of those who received the benefit and those who subsequently took the leave. With the legal changes becoming effective in 1992, the possibility for employed new parents to take parental leave was disentangled from their entitlement to receive the parental subsidy. Therefore, the federal statistics on parental benefits (Bundesstatistik Erziehungsgeld) which are maintained by the Federal Ministry of Family Affairs no longer convey reliable information on the extent of parental leave.

We therefore supplement the direct evidence by indirect evidence from the official employment statistics in order to gain insight into the quantitative importance of parental leave among female employees, and how it has evolved over time. Such evidence is available, because when reporting their actual weekly market hours worked, employees also report whether or not their actual hours deviate from their normal hours. If they deviate, employees indicate the main reason for that deviation such as illness, vacation, flexible work hours, overtime, or parental leave. We further use this detailed information in order to disentangle the general rise in part-time work of women which started in the 1980s, and business cycle movements in hours worked from parental leave.

We center our attention on married women when studying the quantitative implications of changes in federal parental leave and benefit policies on women's labor market involvement. That's because married women are the only group for which the official statistics provide separate information on the labor market behavior of those who have children below the age of ten years, and those who don't. Moreover, it is also well known that between 1987 and 1991, over ninety-eight percent of all recipients of a parental subsidy were women. Out of these women, about ninety percent were married and lived together with their spouse. Our "natural" experiment consists of married employees without young children- the control group-, and married employees with small children- the treatment group- whose members may receive a parental benefit or take parental leave.

Figure $4 \mathrm{a}$ draws a clear picture of how the real monthly parental benefit per recipient female and male - has developed since this transfer payment was introduced in 1986. The average subsidy drastically increased between 1987 and 1991 and dropped significantly when the legal changes became effective in 1992. In fact, there are clear signs of a structural break occuring in the early 1990s. Since then, the average parental benefit received has remained rather stable. 
Because the nominal monthly payment has not been adjusted since 1986, these figures suggest that during the first five years after the first law on parental benefits became effective, eligible individuals adjusted their behavior such as to receive an increasing monthly payment. They could do so, e.g., by reducing their market hours worked, and thereby their income, prior to becoming a new parent. The observed decline in the average monthly benefit which occurred in the early 1990s is due to the fact, that since 1992, the parental subsidy can be received for a maximum of two years, and that any payment after six months is means-tested. Furthermore, entitled individuals have been able to ex ante choose between receiving a maximum monthly amount of $900 \mathrm{DM}(=460 €)$ for at most one year, or a maximum of 600 DM (=307 €) per month for at most two years. Taken together, these factors have driven down the average monthly benefit payment per recipient.

The fraction of new mothers who receive a parental subsidy equals the number of new female recipients of a parental subsidy in a given year relative to the total number of births in that year. A careful look at this fraction reveals the following two phenomena. Firstly and not surprisingly, the fraction is significantly higher for all new mothers than for those mothers who were employed at the time of delivery. For example, in 1987 the ratio equaled ninty-six percent for the first group and eighty-two percent for the latter group. Secondly, this ratio has declined over time; it reached eighty-five percent in 2002 for all mothers and eighty percent for employed mothers in 1991. (No separate evidence on this latter group is available beyond 1991.) This drop most likely is due to the recent legal changes which allow mothers on parental leave to work up to thirty hours per week.

Finally, when restricting our attention to married female employees, between 1987 and 1991 close to seven percent of them were on parental leave and worked zero hours. ${ }^{9}$ These figures are the clearest direct evidence on the quantitative importance of parental leave among married female employees which we report in this paper. They are consistent with the figures which we infer from indirect evidence (see table A2).

We provide indirect evidence on the quantitative importance of parental leave among married women which we derive from the Federal Statistical Office's employment statistics. We look at the fraction of employed married females working at most twenty hours per week and compare the actual hours to the normal hours worked. We focus on female employees working at most twenty hours per week, because women on parental leave could work up to ninteen hours (fifteen hours) per week until the end of 2000 (1988). Next, we select the fraction of married female employees for whom the actual hours worked are less than their 
normal hours and indicate the reason for this deviation. We provide this evidence for the three years in which major changes in the law on parental support (Bundeserziehungsgeldgesetz) became effective, i.e., for 1986, 1992, and 2001, and also for the years preceding those legal changes. This enables us to assess the impact that the various legal changes had on the labor market behavior of married women with and without children below the age of ten.

Table A2 presents upper bounds on the incidence of parental leave without part-time work among married women with young children, illustrating how this incidence was linked to changes in the federal law regulating parental leave. All figures are based on the Federal Statistical Office's employment statistics. They illustrate that following the introduction of parental leave in 1986, married women only gradually adjusted their labor market behavior to this new opportunity of taking time off from their job while raising their children at home. Between 1986 and 1991, the fraction of married women who went on leave rose from 4.4 percent to over ten percent. With the new possibility of taking parental leave without being eligible for parental subsidies, that fraction jumped by 2.5 percentage points in 1992 and continued to rise until the turn of the century. When new parents were allowed to combine parental leave with part-time work of up to thirty hours per week in 2001 , the fraction of married women with young children who took a leave without part-time work started to decline.

Figures $4 \mathrm{~b}$ through $4 \mathrm{~d}$ illustrate the distribution of married female employees' weekly hours worked for the three points in time when changes in the law on parental support became effective; each figure shows the distribution for married women with children below the age of ten and for married women without those children. Figures $4 \mathrm{e}$ through $4 \mathrm{~h}$ indicate the extent to which the actually observed weekly hours coincided with the normal hours worked. They also indicate the reason for deviations between actual and normal weekly hours.

Figure 4b suggests that the legal changes which became effective in 1986 left the hours distribution for the two groups of married female employees almost unaffected. Prior to 1986, married women with young children were more likely to work less than twenty hours per week and also less likely to work around forty hours per week than women from the control group. In 1986, both groups' hours distribution changed in a similar fashion: weight shifted away from the tails towards the center of the respective distribution. While for married women with young children the fraction of weekly hours in the category 'between ten and twenty' increased by more than the fraction in the category 'between thirty and forty', the opposite held true for the control group. Figures $4 \mathrm{e}$ and $4 \mathrm{f}$ shed some light on the motives

\footnotetext{
${ }^{9}$ This figure is computed as follows. 8.7 percent of all married female employees had a child in 1987; 82 percent
} 
underlying the observed changes. On the one hand, the fraction of married employees working at most twenty hours per week for whom the actual hours are less than their normal hours declined between 1985 and 1986 to less than twenty percent, indicating that an increasing fraction of these women reduced their regular weekly hours. On the other hand, among the married women with young children for whom the observed hours were less than their normal hours, the fraction who attributed this discrepancy to parental leave significantly increased from sixty percent in 1985 to seventy-two percent in 1986. This observation clearly shows that many eligible married women took advantage of parental leave when it was first introduced.

Figures 4c, 4g and 4h convey the respective information for 1992. By 1991, well over fifty percent of married female employees with small children worked at most twenty hours a week as opposed to only thirty percent of the women in the control group. Also, over ten percent of married women with young children worked zero hours, as opposed to only three percent of married women without young children. Figure $4 \mathrm{~g}$ suggests that much of this observed difference in the hours distribution of the two groups was due to parental leave policy. For over twenty-five percent of married women with young children at most twenty hours per week were less than their normal hours, and eighty percent of them attributed this discrepancy to other reasons, including parental leave. According to figure 4h, with the legal changes becoming effective in 1992, the fraction rose to over thirty percent. In sum, there is compelling evidence that the legal separation between parental leave and parental subsidy together with the increase of the maximum leave period from two to three years let to an overall rise of parental leave among married women, thereby contributing to the decline in the weekly hours worked by that group.

By the year 2000, the fraction of married women with young children who worked less than twenty hours per week had risen to almost seventy percent; twenty percent worked zero hours, and over thirty-five percent worked betweeen ten and twenty hours per week. Figure $4 \mathrm{~d}$ supports the evidence stated in table A2 that the legal changes which became effective in 2001 successfully induced some married women with young children who bok parental leave to start working part-time. Remarkably, even though individuals on parental leave were entitled to work up to thirty hours per week, the reform of 2001 reduced the fraction of married employees working between twenty and thirty hours per week and instead increased the fraction working between one and ten, or between ten and twenty hours per week.

of them received a parental subsidy; and 96 percent of those women worked zero hours. 


\section{CONClusions}

This paper provides strong evidence that drawing a reliable picture of women's labor market involvement in Germany requires one to not only look at the employment-to-population ratio, but also at women's hours worked if employed. Using aggregate time-series data from the German micro census covering the period from 1957 through 2002, the paper illustrates that the EP-ratio has gradually risen among female employees of all marital statuses and of consecutive cohorts. The average female EP-ratio in Germany has moved towards that of men in the country, but it still falls short of the ratio observed for women in the United States by almost ten percentage points. The evidence further suggests that the observed rise in women's EP-ratio has been accompanied by a notable decline in their weekly hours worked.

The paper points to married women with young children as a significant group of female employees for whom the changes in the extensive and the intensive margin have been the most severe. Since 1975, this group of women has steadily reduced its weekly hours' involvement by over forty percent. Since the mid 1980s, the EP-ratio of this group has doubled to over sixty percent, thereby exceeding the ratio of single women.

We argue that institutional changes in the federal legislation governing parental leave contributed to the observed changes in married women's labor market involvement in Germany. We provide ample evidence to support this argument. The strong increase in monthly real payments of parental subsidies to new parents which took place between 1986 and 1991 coincided with a big drop in married women's weekly hours worked and with a doubling of the fraction of married females taking parental leave without part-time work During those five years, the group's employment-to-population ratio grew by almost ten percentage points to over 43 percent; it continued to strongly rise thereafter. This observation is consistent with the finding by Ruhm (1998) for selected European countries that paid parental leave raises the percentage of women employed. When in 1992 the maximal length of parental leave was extended from two to three years and the possibility to take this leave was disentangled from the eligibility for a governmental transfer payment, the fraction of women taking parental leave without part-time work jumped significantly. Similarly, the legal changes which enable new parents on parental leave to work a considerable number of weekly hours while on leave have caused fewer married females to take such a leave and to not work at all. In sum, there is strong evidence that married females have reacted with their extensive and intensive labor market involvement to changes in incentives to work, and that these reactions have considerably affected the development of average weekly hours worked per woman in Germany. 
The results presented leave several important questions unaddressed. For example, it is to be expected that changes in the parental leave policy not only affected the labor market behavior of married women, but also of single and widowed or divorced women. Have their reactions been similiar to those illustrated for married women? Furthermore, the extent to which women react to parental leave policies most likely is linked to their educational level, or to the labor market status of their spouse or partner. All of these issues require further exploration in an effort to complete the picture on the impact that parental leave has had on women's total labor market involvement in Germany. However, such an exploration requires analyzing individual data from the micro census, or from the German Socio-Economic Panel. We leave it for future research. 


\section{REFERENCES}

Bundesministerium für Familien, Senioren, Frauen und Jugend 2002. Bundesstatistik Erziehungsgeld.

Del Boca, D. 2002. "The Effect of Child Care and Part Time Opportunities on Participation and Fertility Decisions in Italy," Journal of Population Economics 15:549-573.

Frank, M. R. Lipner 1988. "History of Maternity Leave in Europe and the United States," in E.F. Zigler, M. Frank (eds.), The Parental Leave Crisis. New Haven, CT: Yale University Press.

German Federal Statistical Office. Yearbook. Various issues. Stuttgart: Kohlhammer. The Population of the Federal Republic of Germany According to the Census of September 13, 1950. Official Statistics of the Federal Republic of Germany Series, 35 (1), Stuttgart: Kohlhammer, 1953.

. The Occupational and Social Composition of the Population of the Federal Republic of Germany According to the Census of September 13, 1950. Official Statistics of the Federal Republic of Germany Series, 36 I (2), Stuttgart: Kohlhammer, 1953.

Jones, L., McGrattan, E., R. Manuelli 2003. "Why Are Married Women Working so Much?" Research Department Staff Report 317. Federal Reserve Bank of Minneapolis.

McGrattan, E., R. Rogerson 1998. "Changes in Hours Worked since 1950," Quarterly Review of the Federal Reserve Bank of Minneapolis, Winter:2-19.

2004. "Changes in Hours Worked, 1950-2000," Quarterly Review of the Federal Reserve Bank of Minneapolis, Summer:14-33.

Olivetti, C. 2001. “Changes in Women's Hours of Market Work: The Effect of the Return to Experience," Working Paper, Boston University.

Organization for Economic Cooperation and Development 1995. "Long-Term Leave for Parents in OECD Countries," in Employment Outlook. Paris: OECD Department of Economics and Statistics.

Ruhm, C. 1998. “The Economic Consequences of Parental Leave Mandates: Lessons from Europe," Quarterly Journal of Economics 113:285-317.

Voicu, A., H. Buddelmeyer 2003. "Children and Women's Participation Dynamics: Transitory and Long-Term Effects. IZA Discussion Paper no. 729. 


\section{APPENDIX}

Table A1: Maternity and Parental Leave Policy in Germany, 1968-2001

\begin{tabular}{c|c|c|c|c}
\hline $\begin{array}{c}\text { Children } \\
\text { Born After }\end{array}$ & $\begin{array}{c}\text { Maximal Duration of } \\
\text { MaternityLeave } \\
\text { (Post-Natal) }\end{array}$ & Parental Leave & $\begin{array}{c}\text { Months of } \\
\text { Entitlement to } \\
\text { Benefits }\end{array}$ & $\begin{array}{c}\text { \# Permitted Weekly } \\
\text { Hours Worked During } \\
\text { Parental Leave }\end{array}$ \\
\hline Jan. 1, 1968 & 2 & 0 & 0 & 0 \\
Jan. 1, 1979 & 2 & 4 & 6 & 0 \\
Jan. 1, 1986 & 2 & 8 & 10 & 15 \\
Jan. 1, 1988 & 2 & 10 & 12 & 15 \\
July 1, 1989 & 2 & 13 & 15 & 19 \\
July 1, 1990 & 2 & 34 & 18 & 19 \\
Jan. 1, 1992 & 2 & 34 & 24 & 19 \\
Jan. 1, 1993 & 2 & 34 & 24 & 30 \\
Jan. 1, 2001 & 2 & & & 19 \\
\hline
\end{tabular}

Source: The law regulating maternity leave and benefits (Mutterschutzgesetz, 1952) the law regulating parental leave and benefits (Bundeserziehungsgeldgesetz, 1985), and various amendments thereof. Note that maternity leave is compulsory and can only be taken by the mother. Parental leave is voluntary and, since 1986, can be taken by the mother or the father.

Table A2: Incidence of Parental Leave without Part-Time Work (Upper Bounds)

\begin{tabular}{c|c|c}
\hline & Married women with kids < 10 & Married women without kids < 10 \\
\hline 1986 & $4.4 \%$ & $.67 \%$ \\
1991 & $10.1 \%$ & $.69 \%$ \\
1992 & $12.5 \%$ & $.92 \%$ \\
2000 & $16.1 \%$ & $.96 \%$ \\
2001 & $14.7 \%$ & $.95 \%$ \\
\hline
\end{tabular}

Source: German Federal Statistical Office, Bevölkerung und Erwerbstätigkeit, Fachserie 1, Reihe 4.1.1, various issues. The entries denote the fraction of the respective group of married female employees working zero hours during the survey week for 'other reasons, including parental leave'. 
Figure 1a: Weekly Market Hours Worked per Person (age 15+)

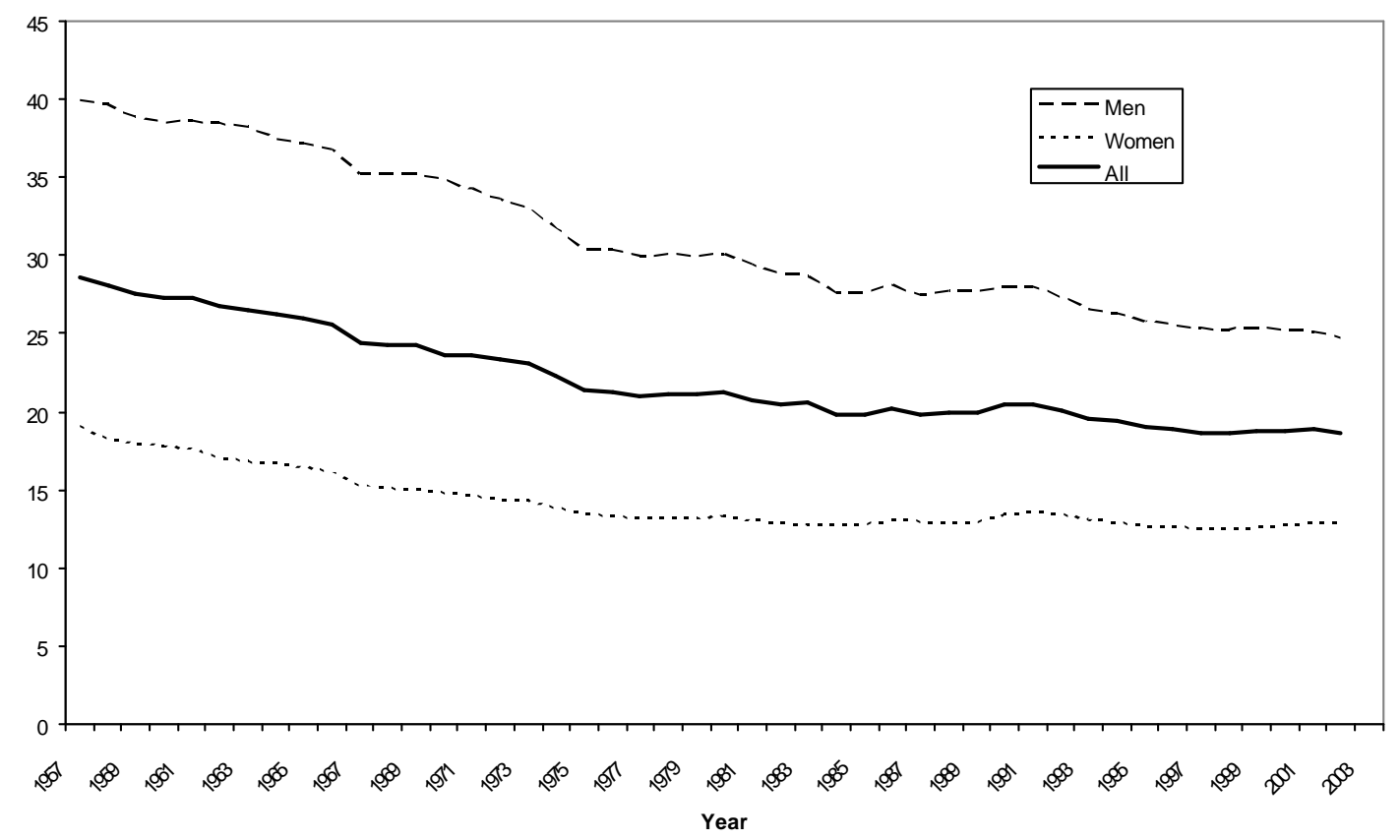

Figure ib: Weekly Hours Worked per Employee (age 15+)

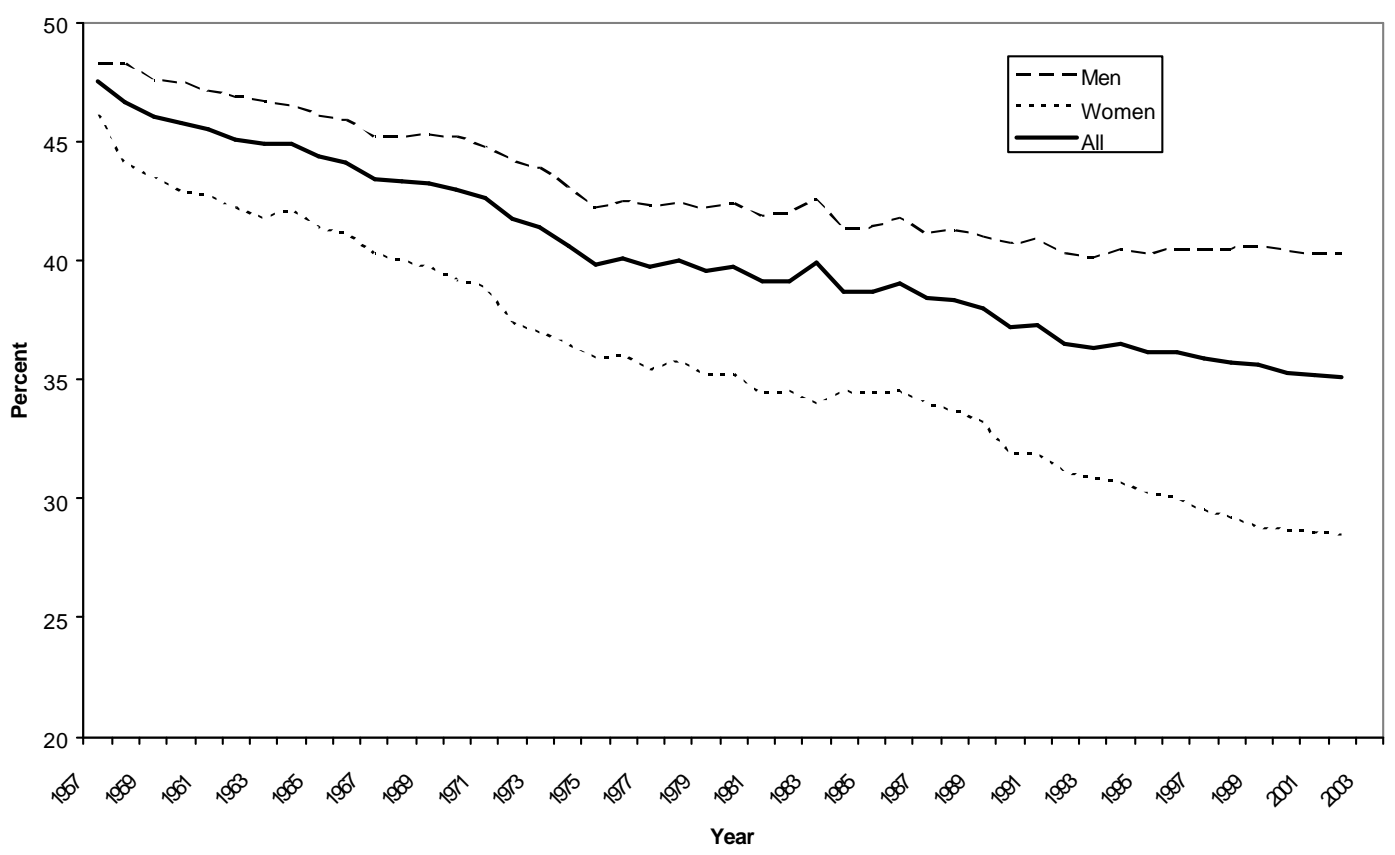

20 
Figure 1c: Employment-to-Population Ratio (age 15+)

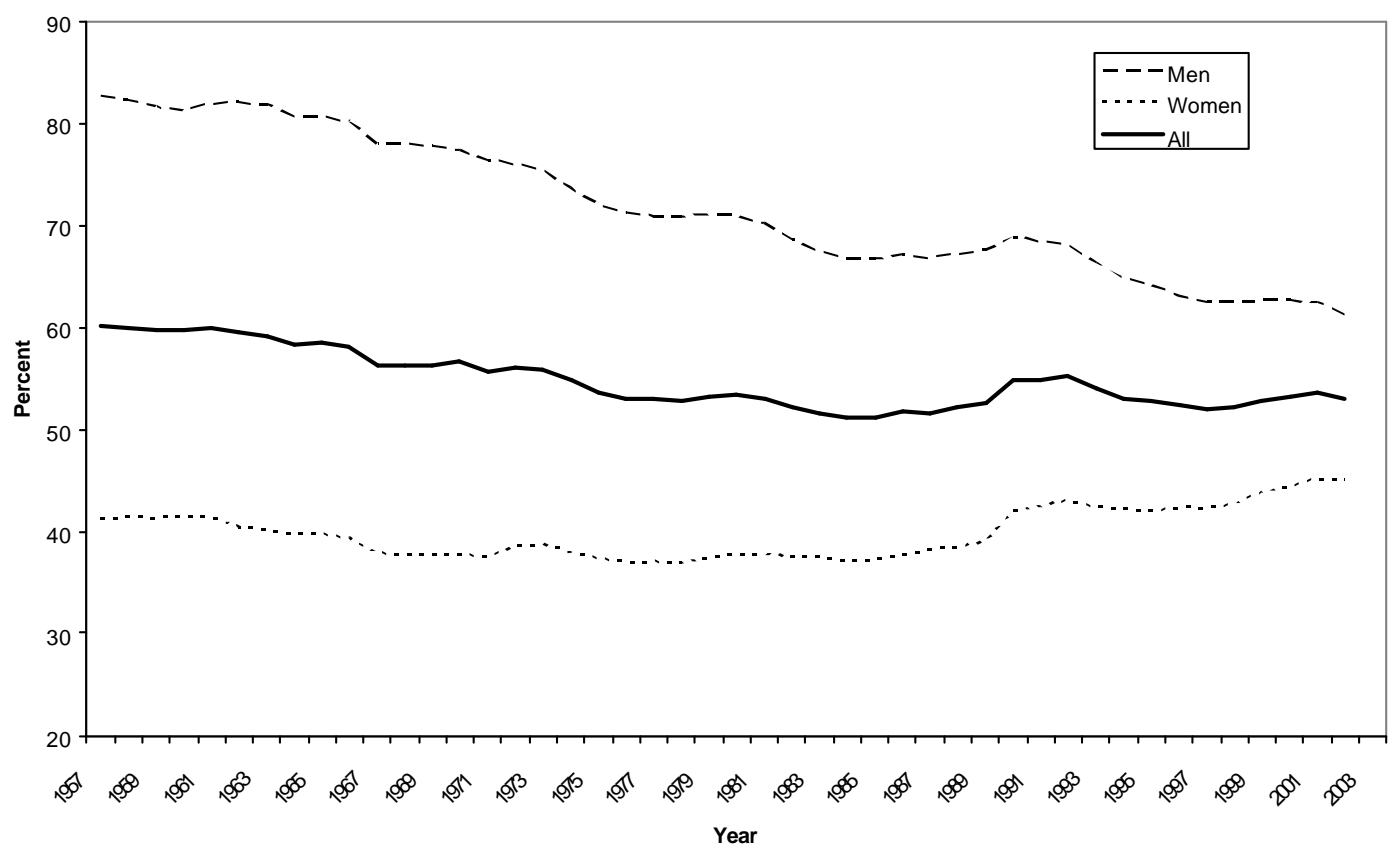

Note: Underlying data originate from various publications of the German Federal Statistical Office on the micro census. Various issues. Author's own calculations.

Figure 2a: Weekly Market Hours Worked per Woman (age 15+)

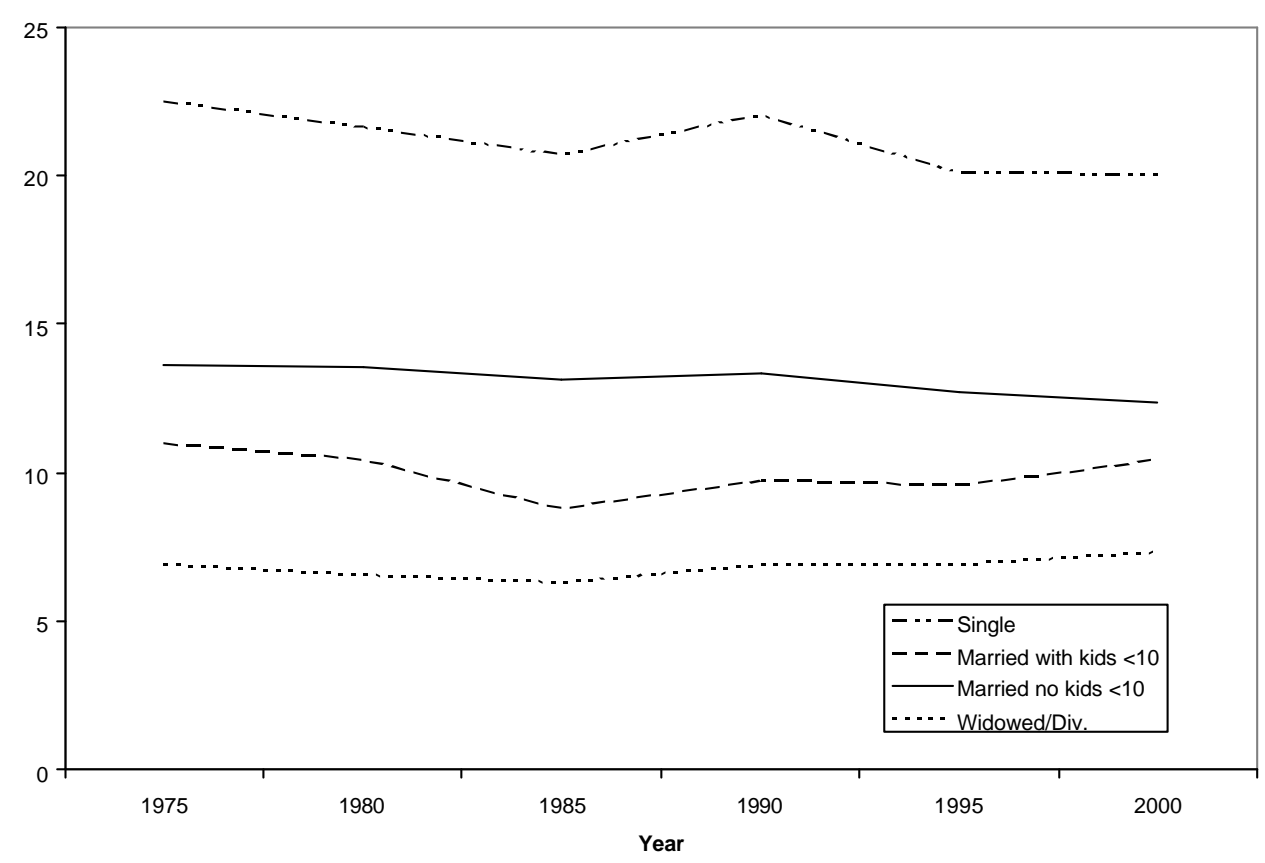


Figure 2b: Weekly Market Hours Worked per Female Employee (age 15+)

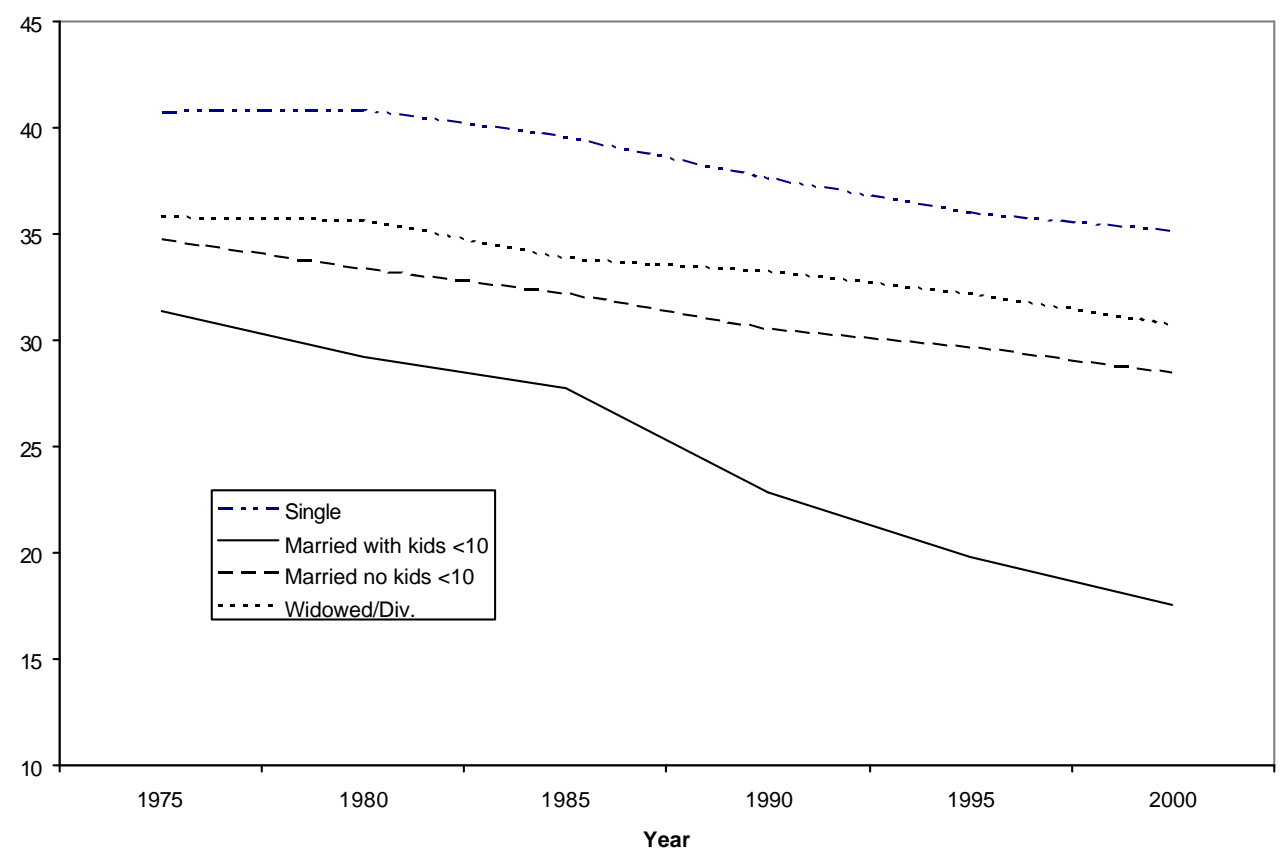

Figure 2c: Women's Employment-to-Population Ratio (age 15+)

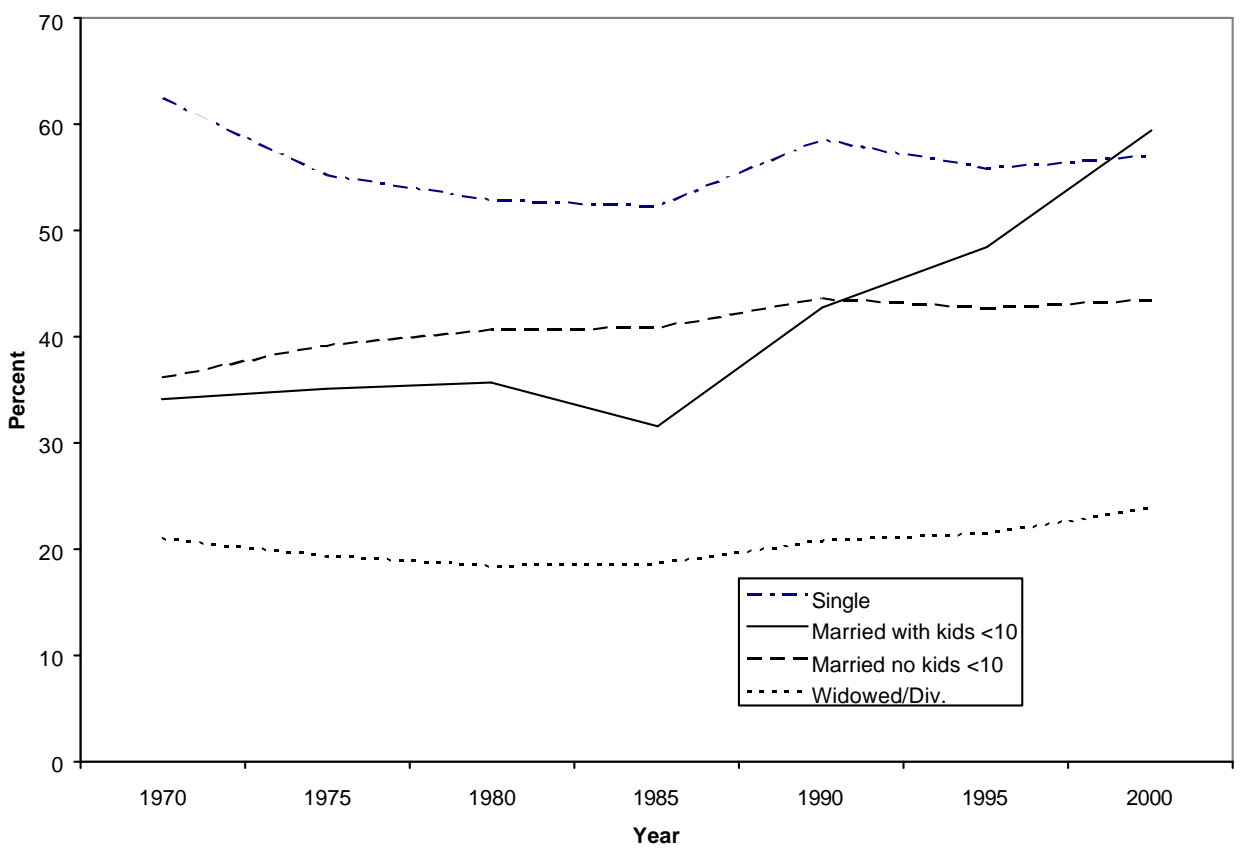

Note: See figure 1. 
Figure 3: Women's Employment-to-Population Ratio by Cohorts at Various Ages

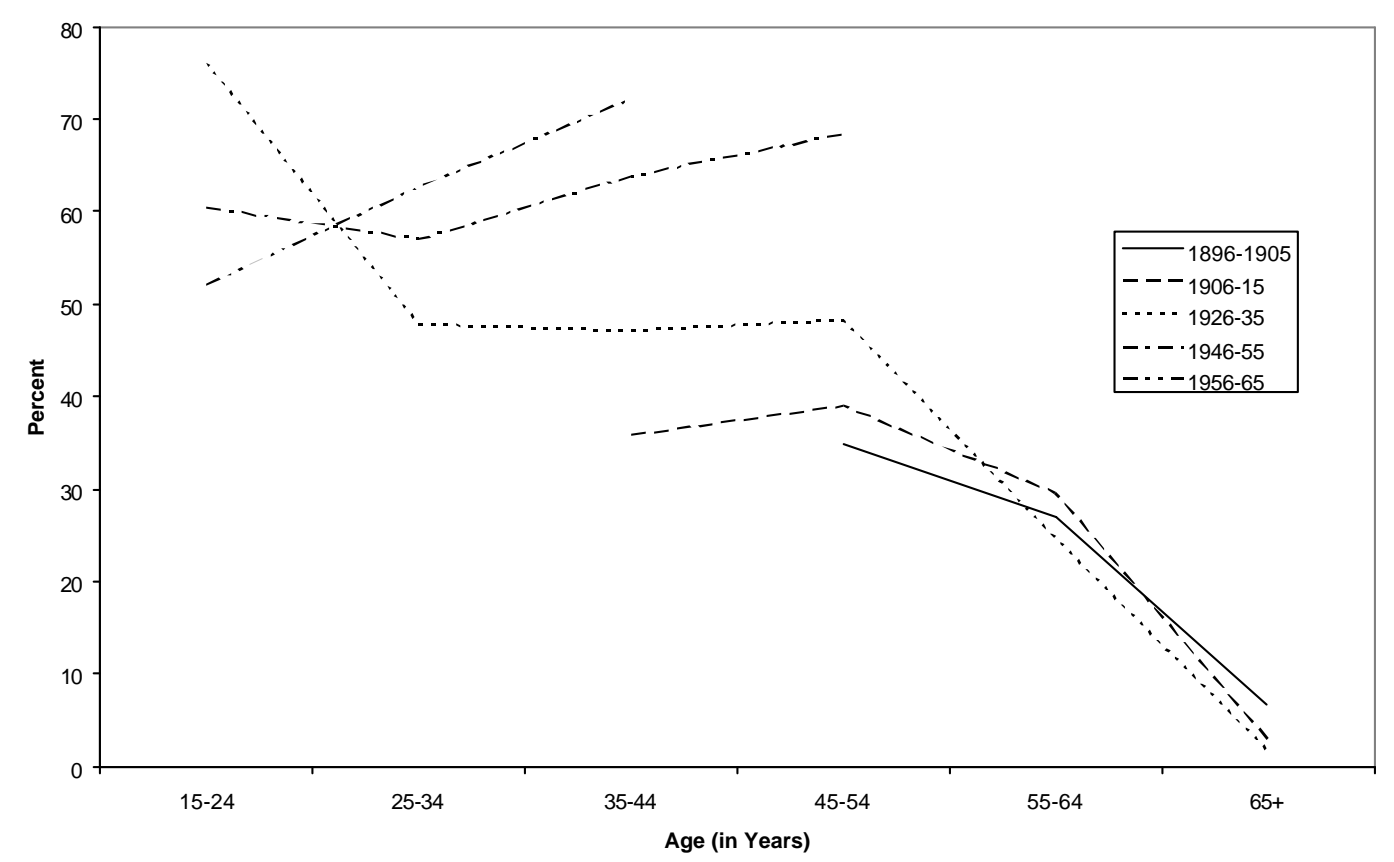

Note: See figure 1. The data for 1950 originate from the census which was held on September 13, 1950. They do not cover the states Saarland and West-Berlin.

Figure 3a: Weekly Market Hours Worked per Married Employee with Young Children

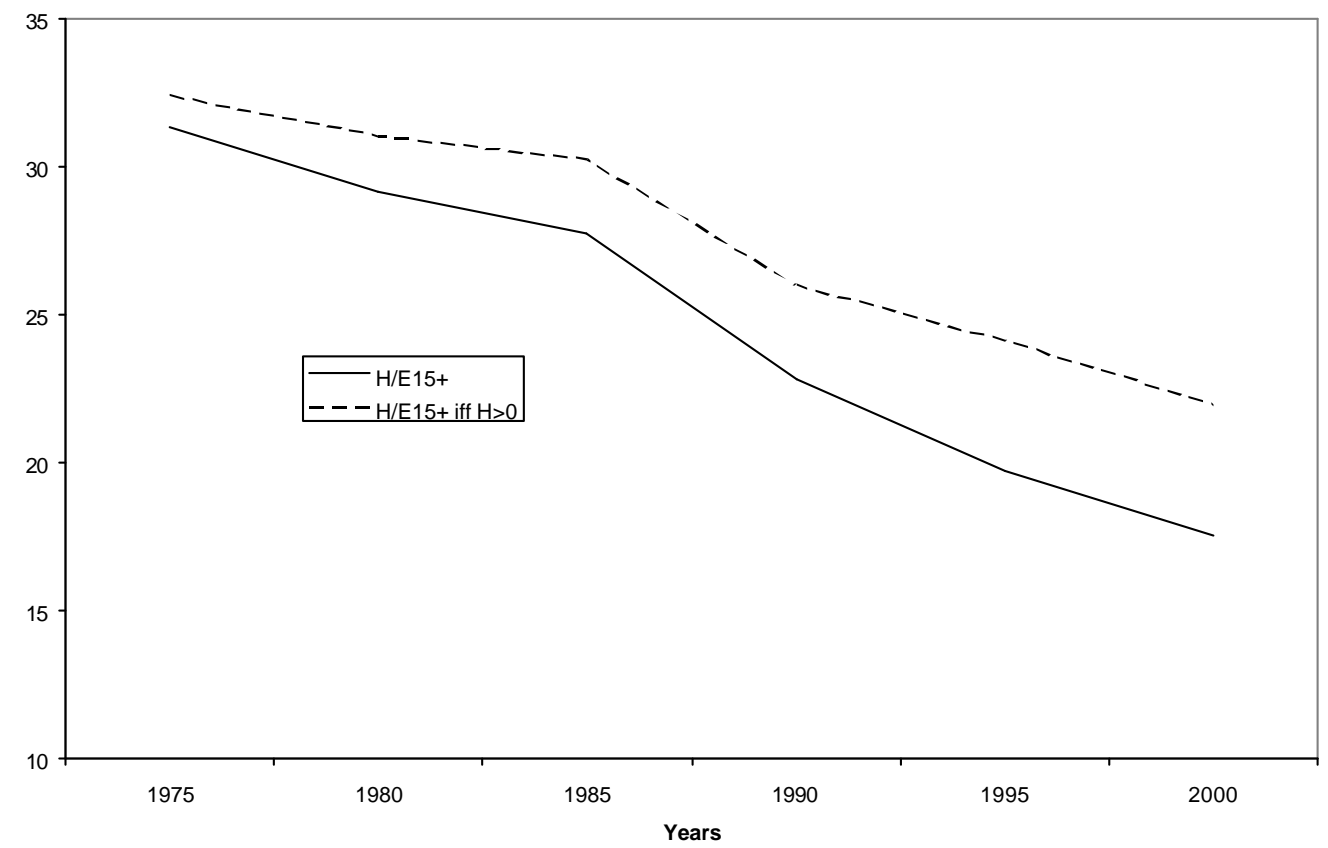


Figure 3b: Employment-to-Population Ratio for Married Women with Young Children

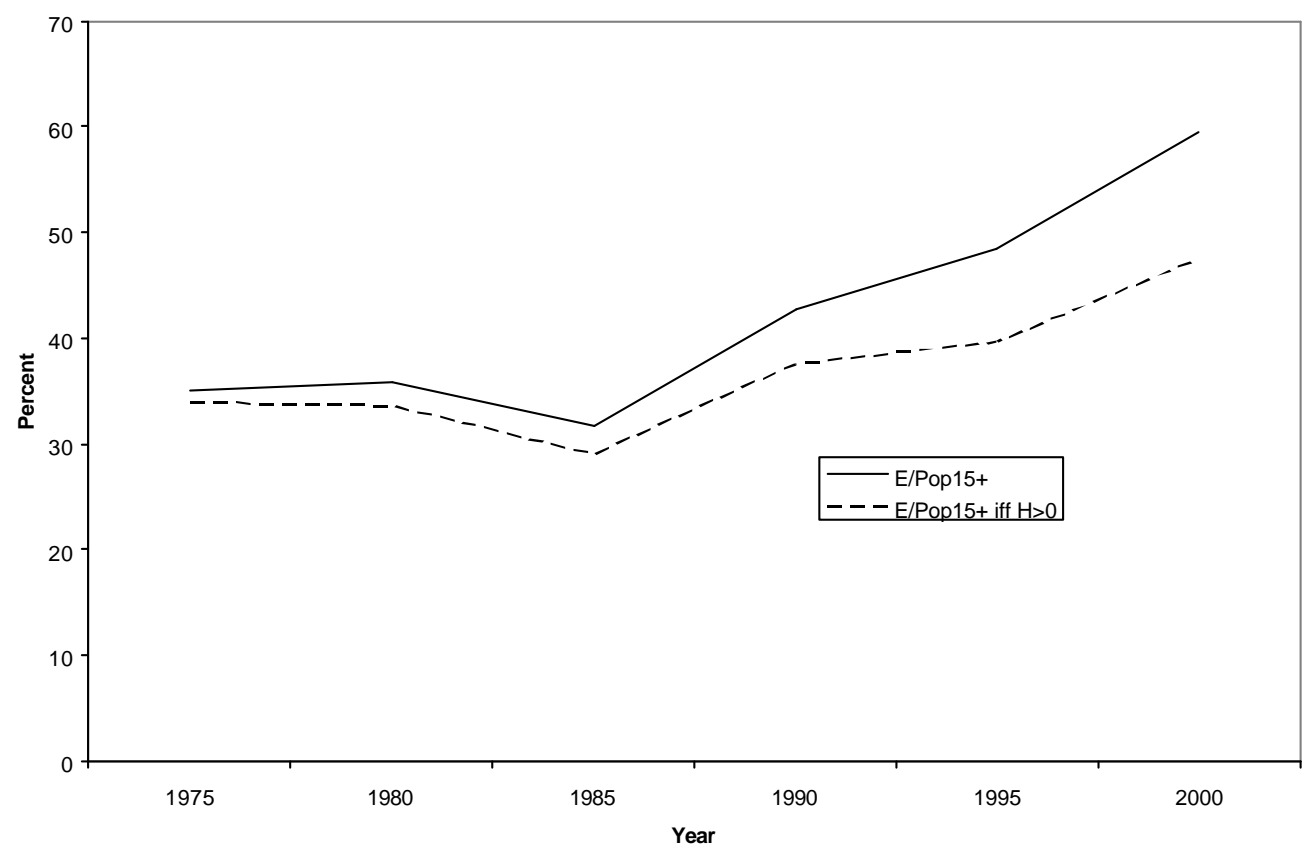

Figure 4a: Real Monthly Parental Subsidy per Recipient in DM (1991=100)

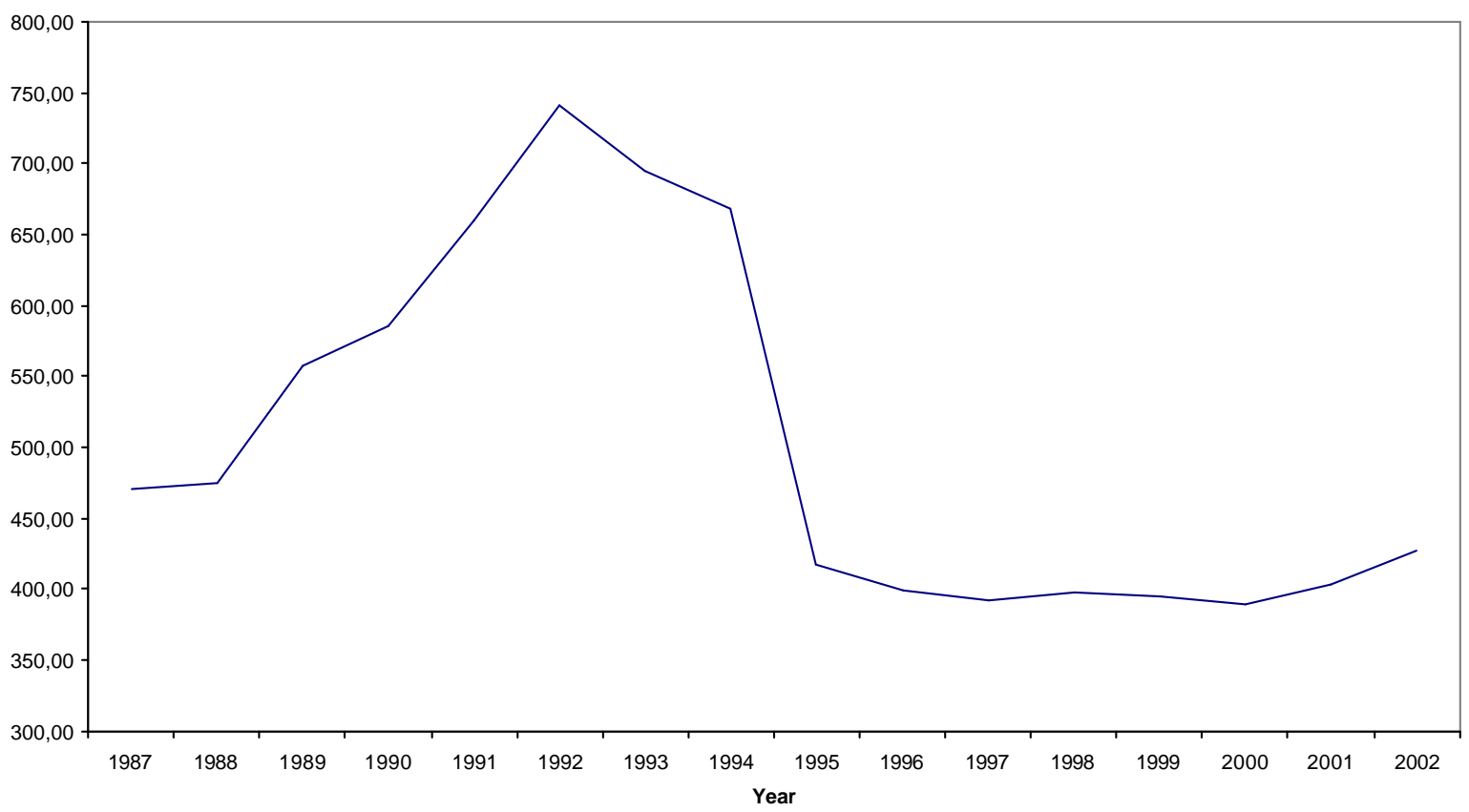

Source: German Federal Statistical Office, Yearbook, various issues; German Federal Ministry of Family Affairs, Bundesstatistik Erziehungsgeld 2002. Own calculations. 
Figure 4b: Distribution of Weekly Hours by Married Women with Kids < 10 Yrs. Across Hours Intervals, 1985 vs. 1986

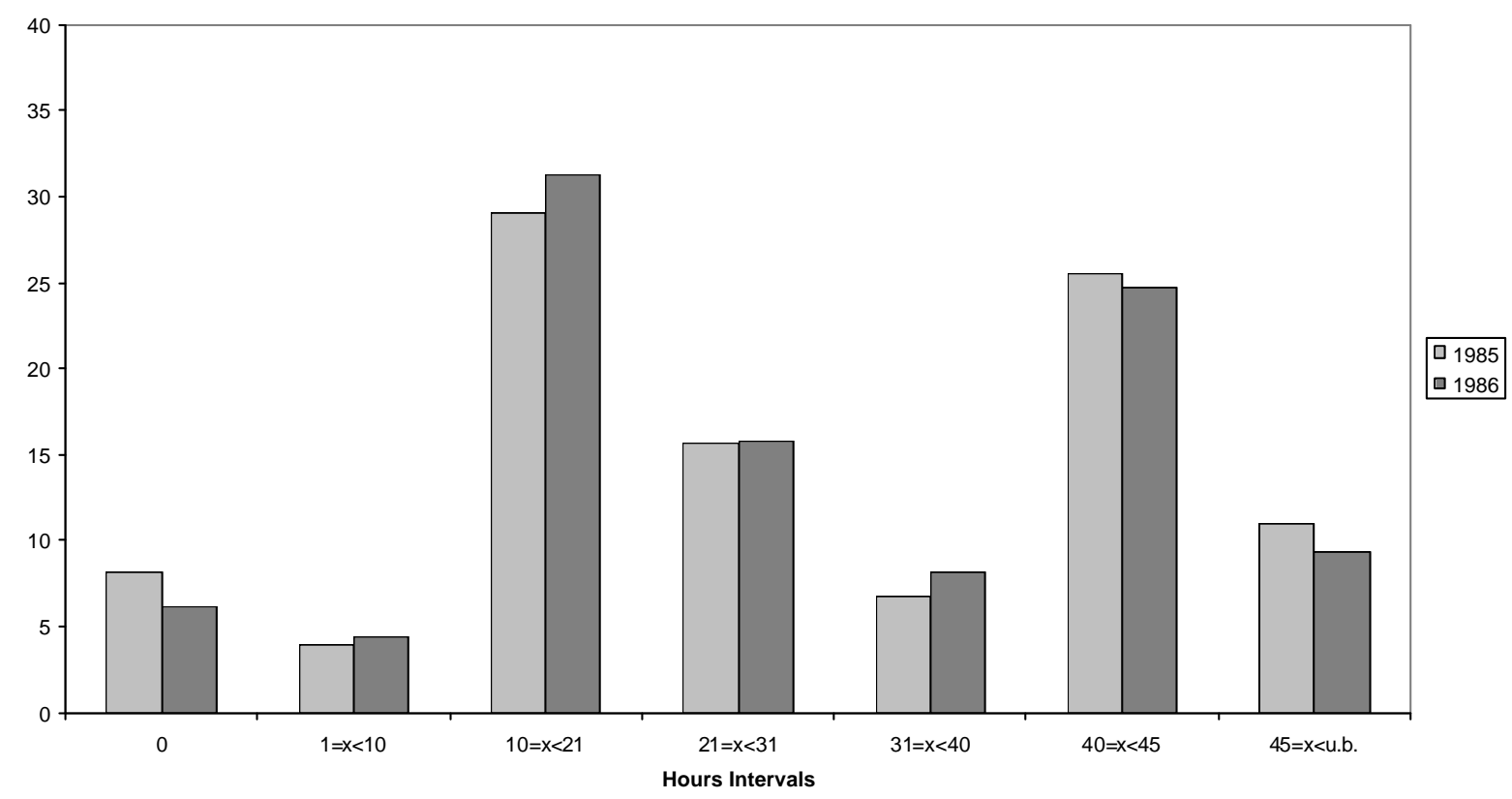

Distribution of Weekly Hours by Married Women Without Kids < 10 Yrs. Across Hours Intervals, 1985 vs. 1986

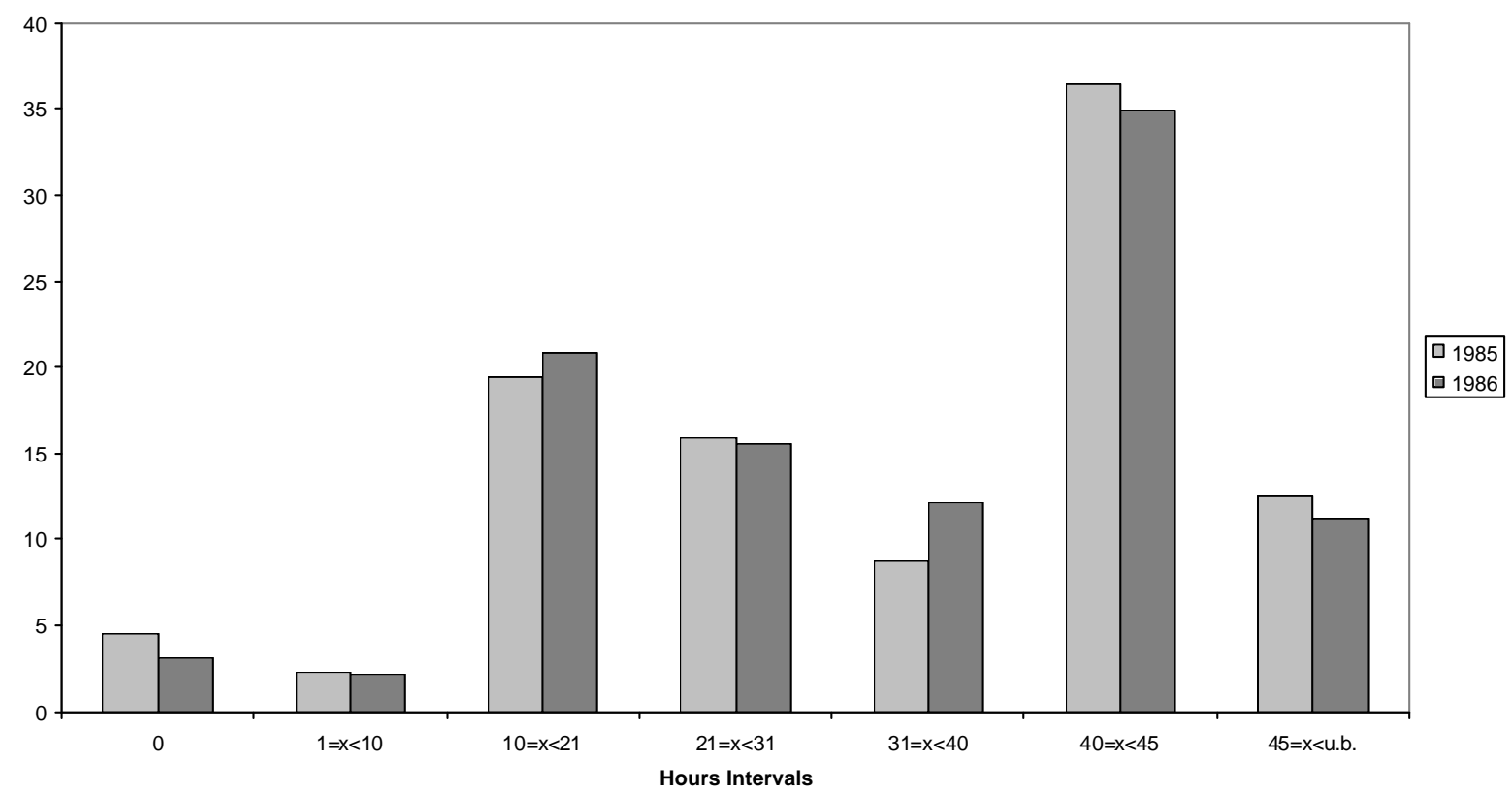


Figure 4c: Distribution of Weekly Hours by Married Women With Kids $<10$ Yrs. Across Hours Intervals, 1991 vs. 1992

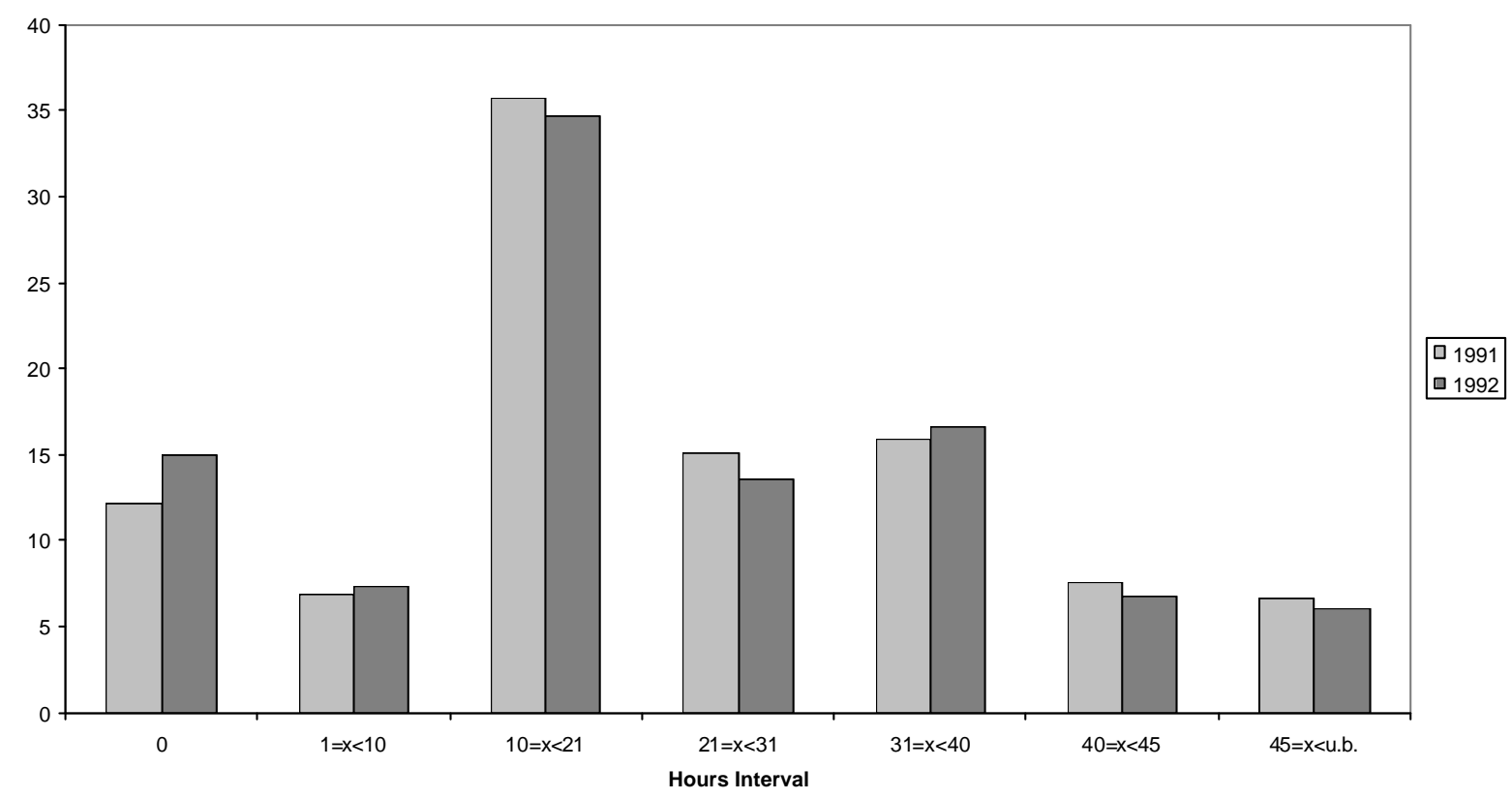

Distribution of Weekly Hours by Married Women Without Kids < 10 Yrs. Across Hours Intervals, 1991 vs. 1992

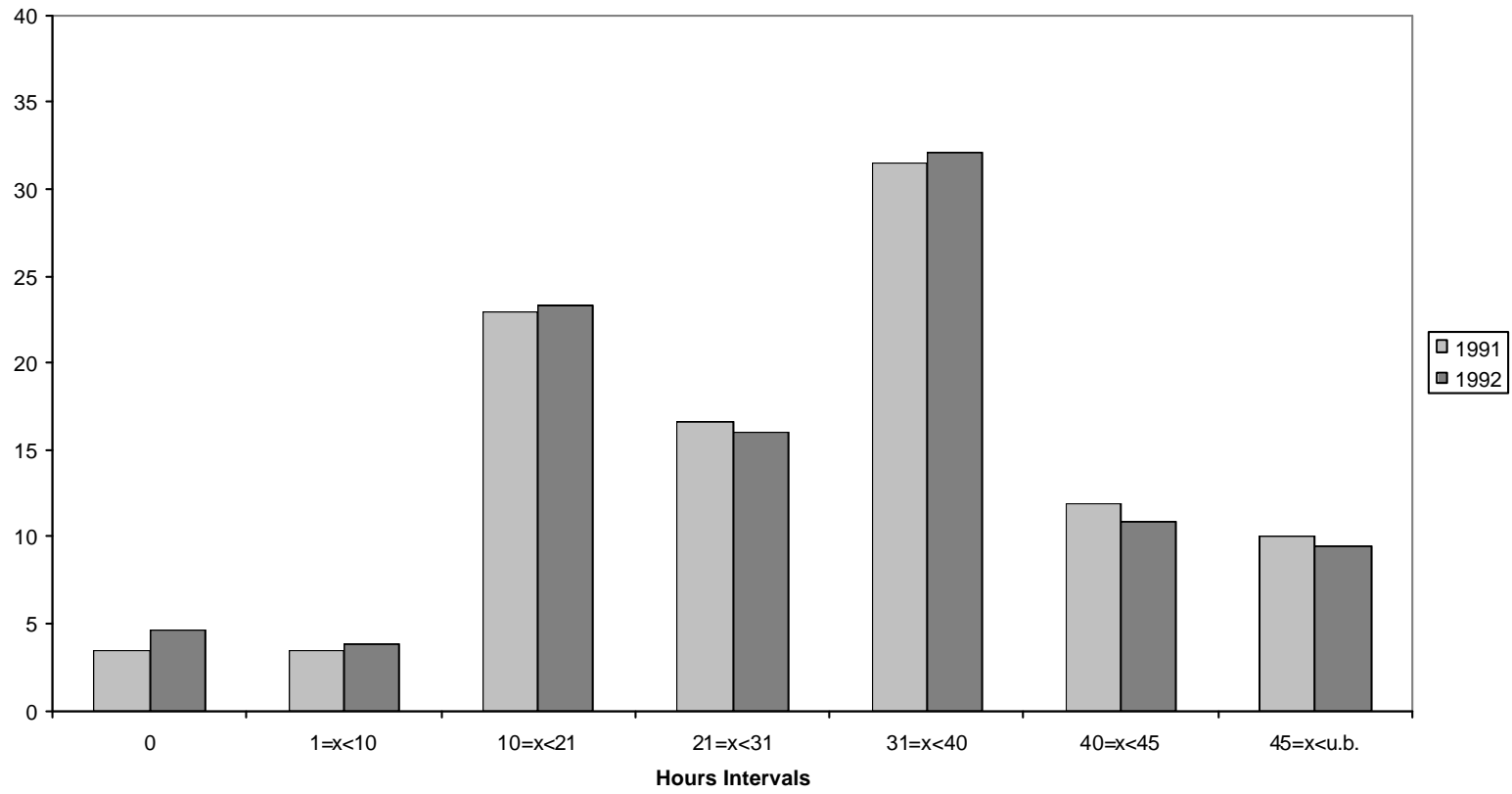


Figure 4d: Distribution of Weekly Hours by Married Women with Kids < 10 Yrs. Across Hours Intervals, 2000 vs. 2001

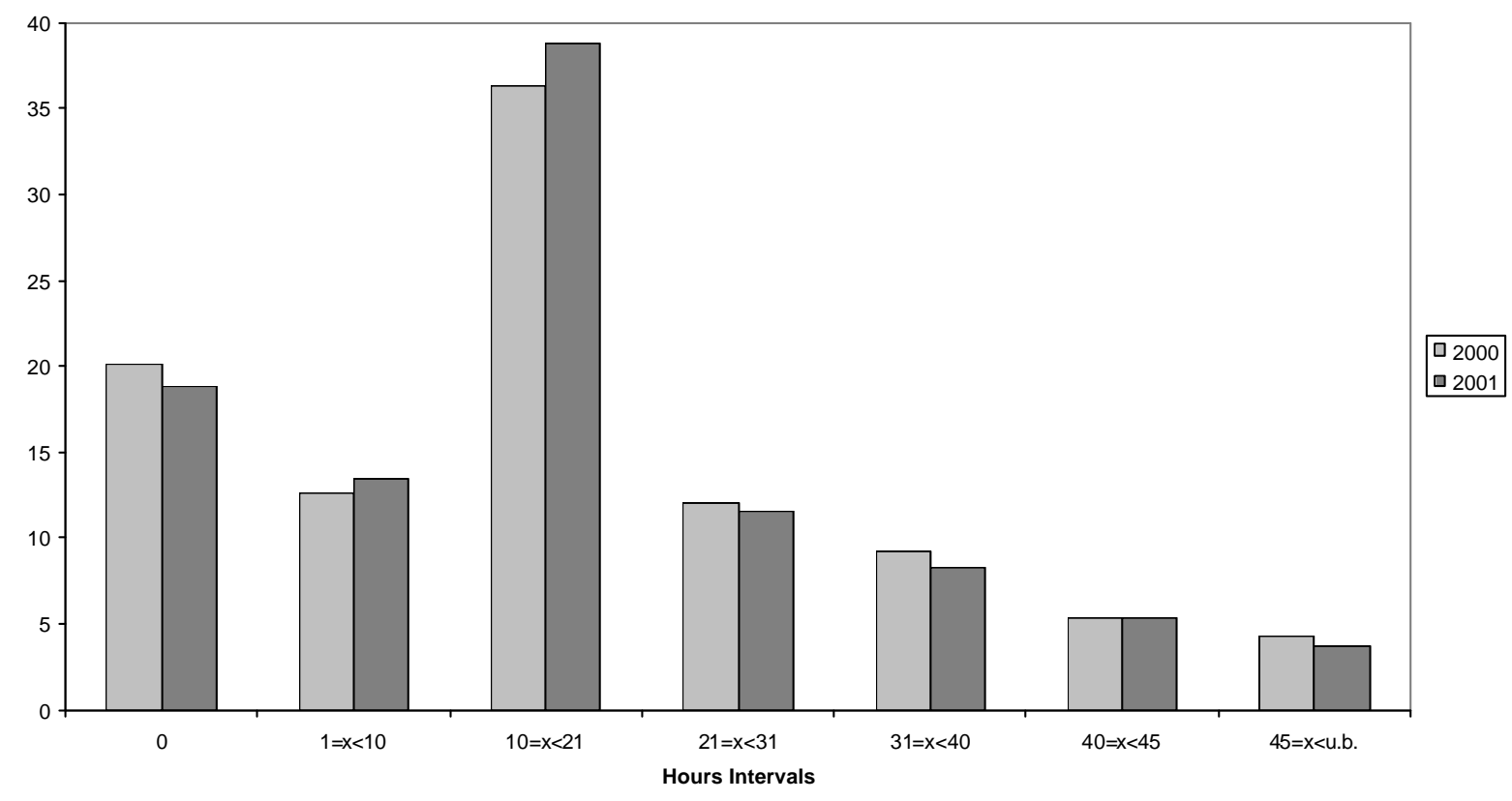

Distribution of Weekly Hours by Married Women Without Kids $<10$ Yrs. Across Hours Intervals, 2000 vs. 2001

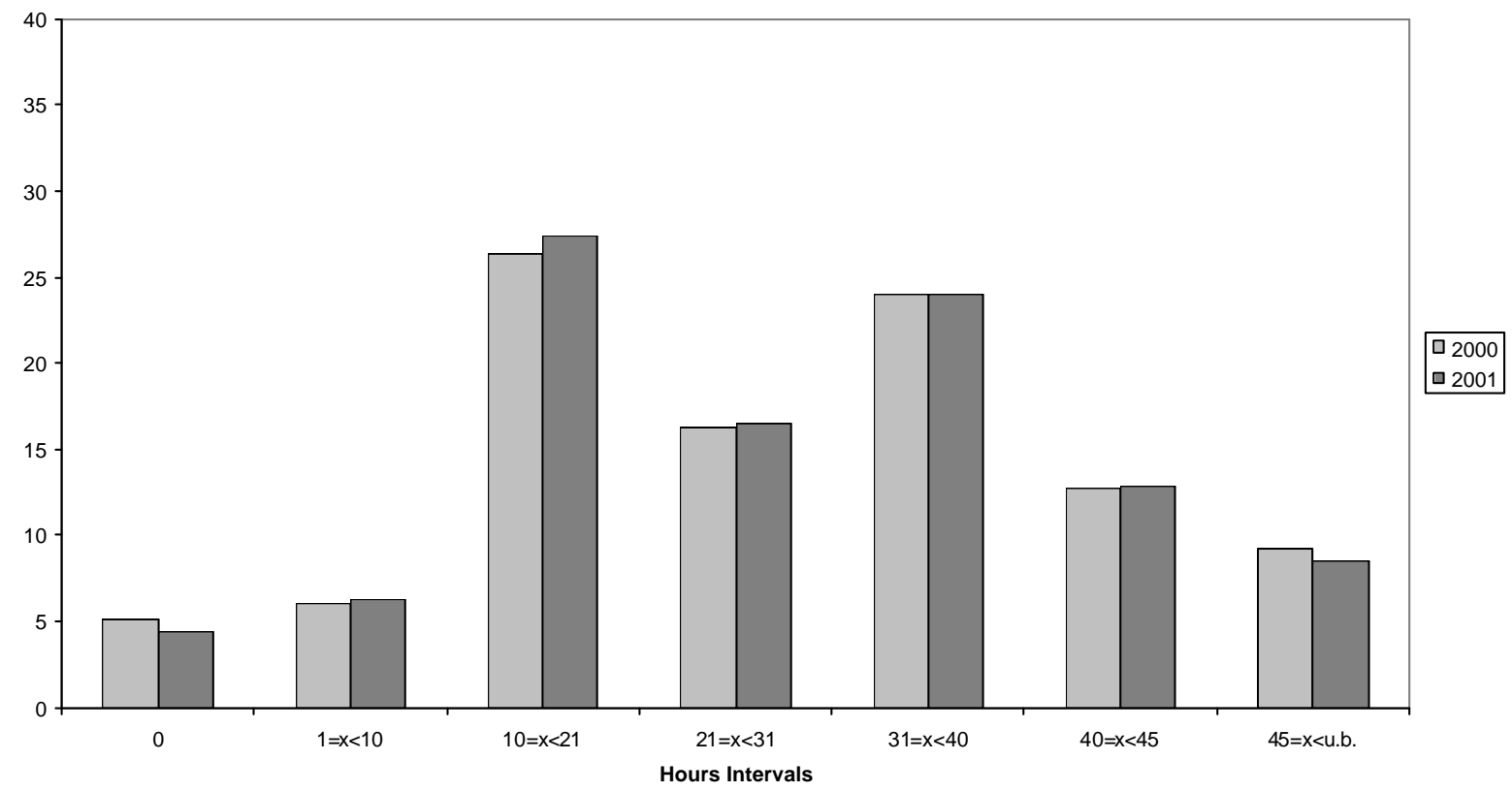


Figure 4e: Fraction of Married Women Working at Most 20 hrs./week for Whom Actual Hours are ... Normal Hours, 1985

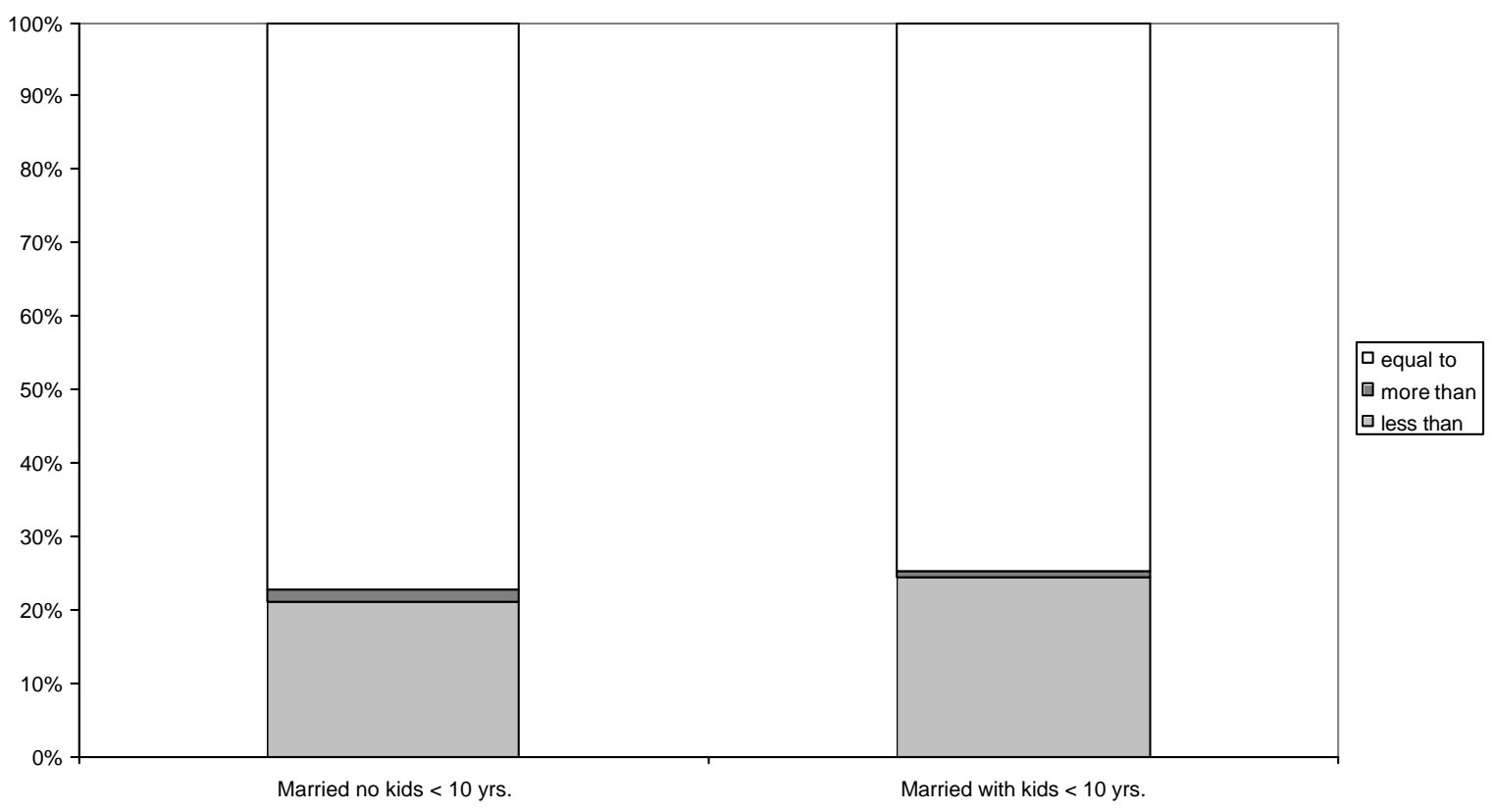

Fraction of Those Women For Whom at Most 20 hrs./week are Less Than Their Normal Hours, Where Deviation is Due To ..., 1985

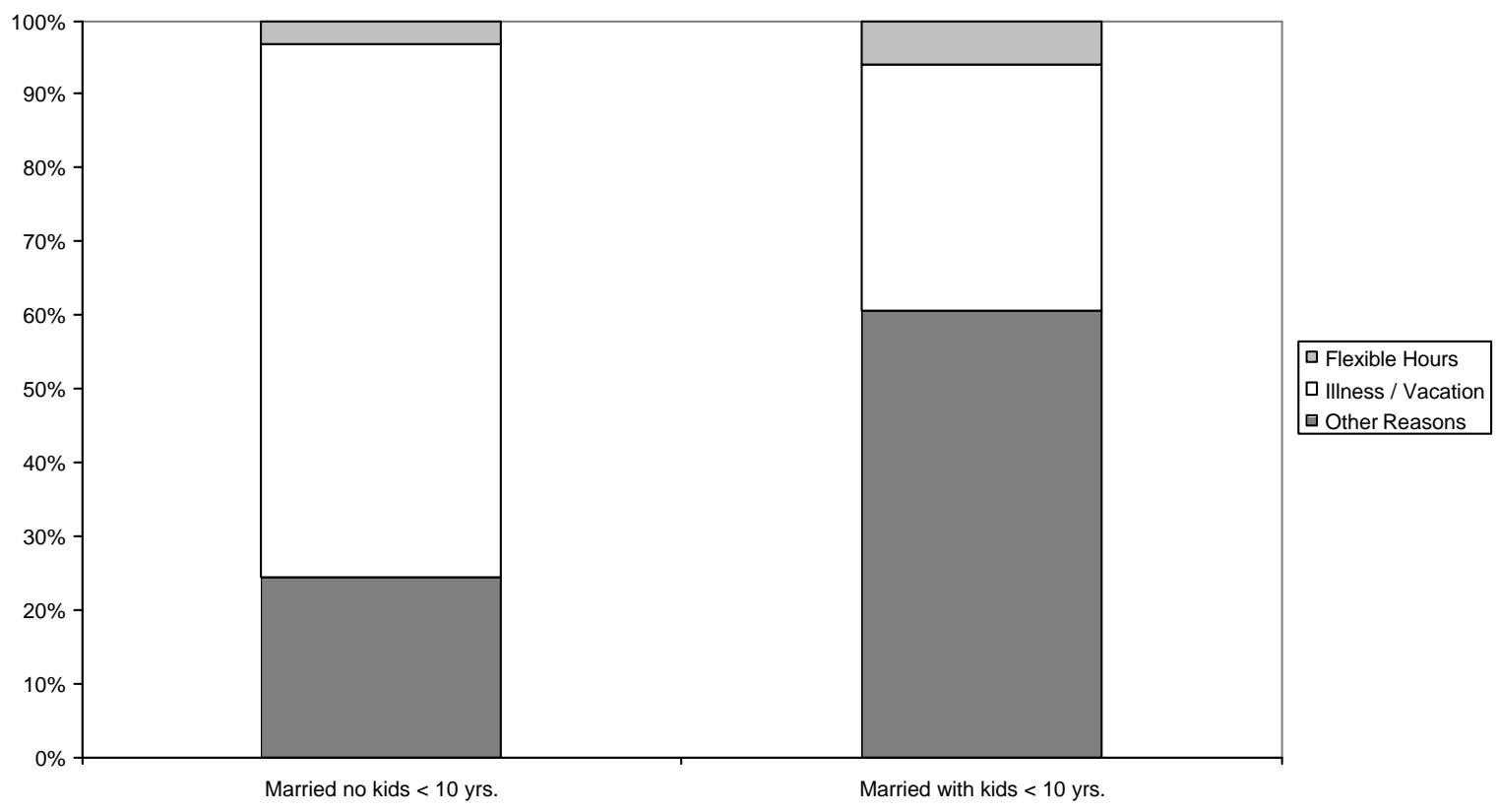


Figure 4f: Fraction of Married Women Working at Most 20 Hrs. /Week for Whom Actual Hours Are ... Normal Hours, 1986

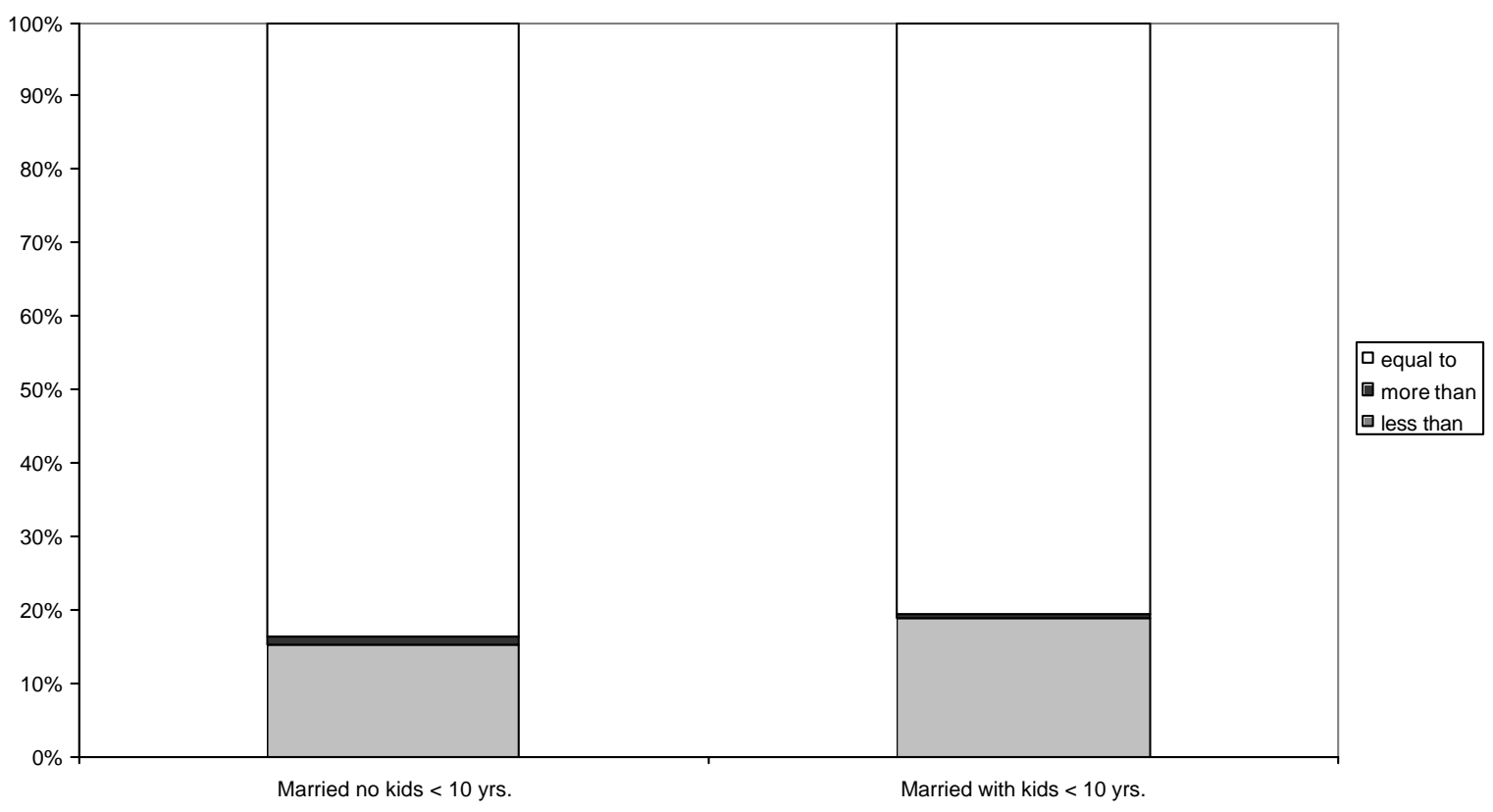

Fraction of Those Women for Whom at Most $20 \mathrm{hrs}$./week are Less Than Their Normal Hours, Where Deviation is Due To ..., 1986

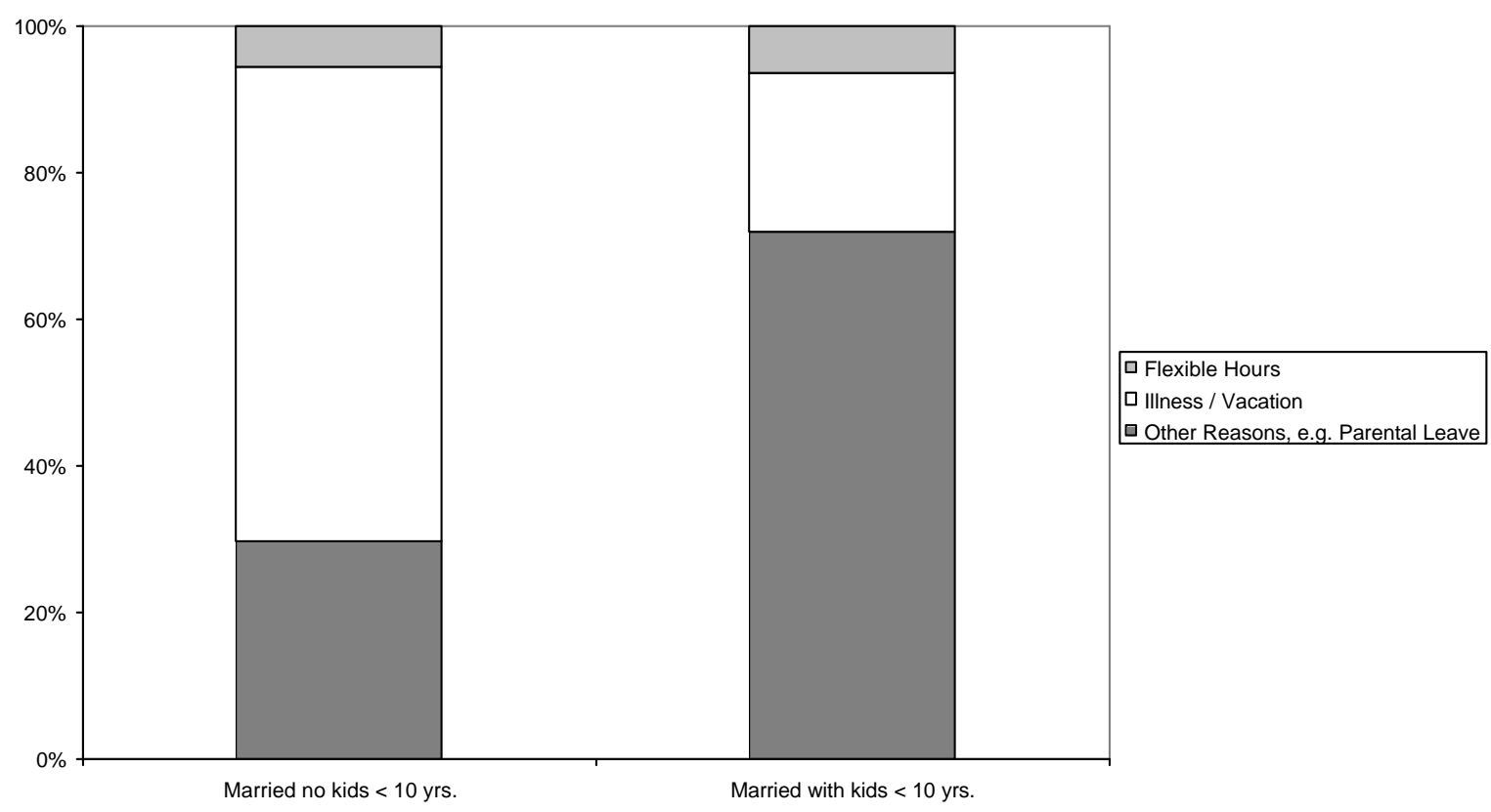


Figure 4g: Fraction of Married Women Working at Most 20 hrs./week for Whom Actual Hours are ... Normal Hours, 1991

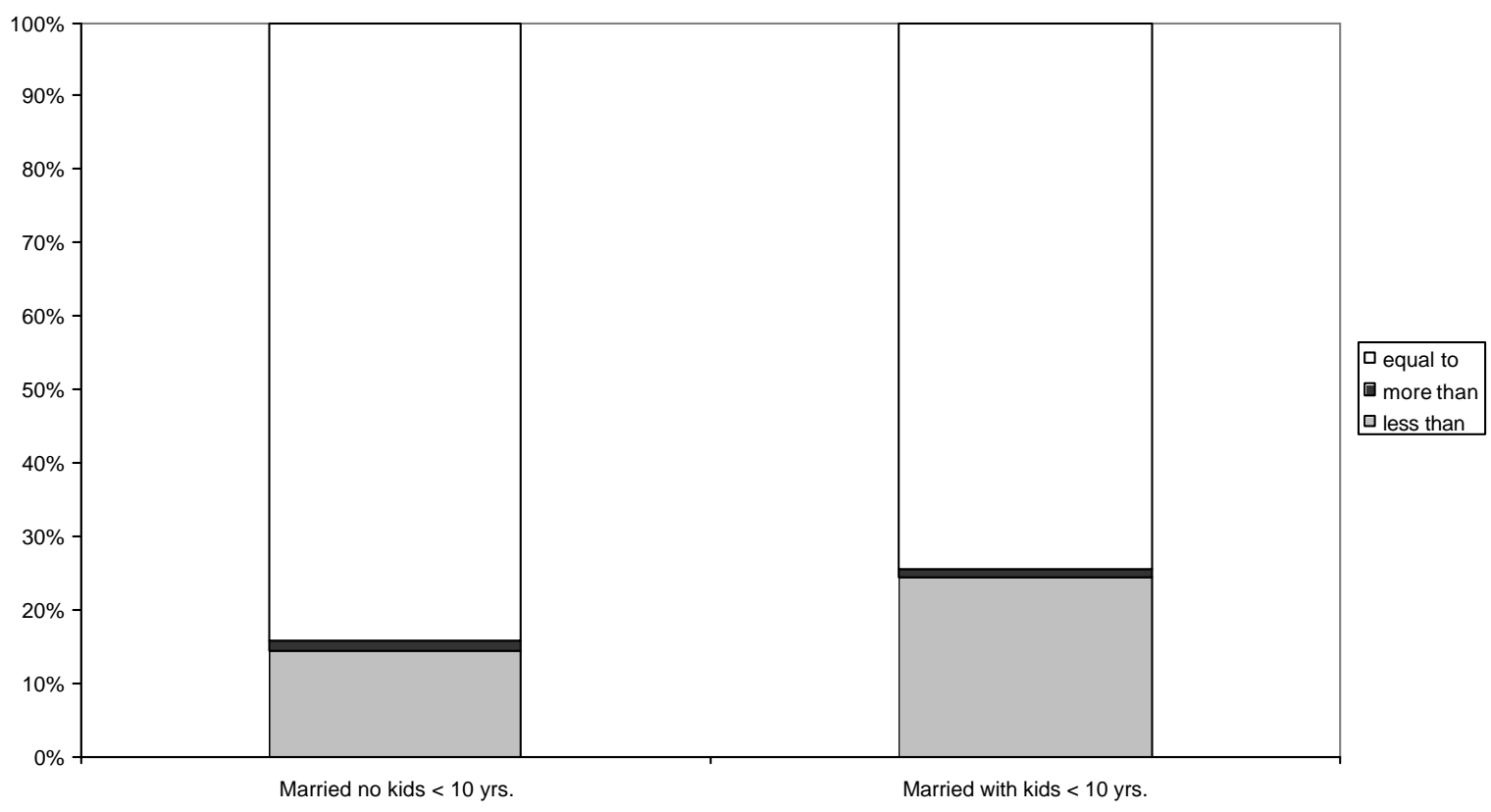

Fraction of Those Women For Whom at Most 20 hrs./week are Less Than Their Normal Hours, Where Deviation is Due To ..., 1991

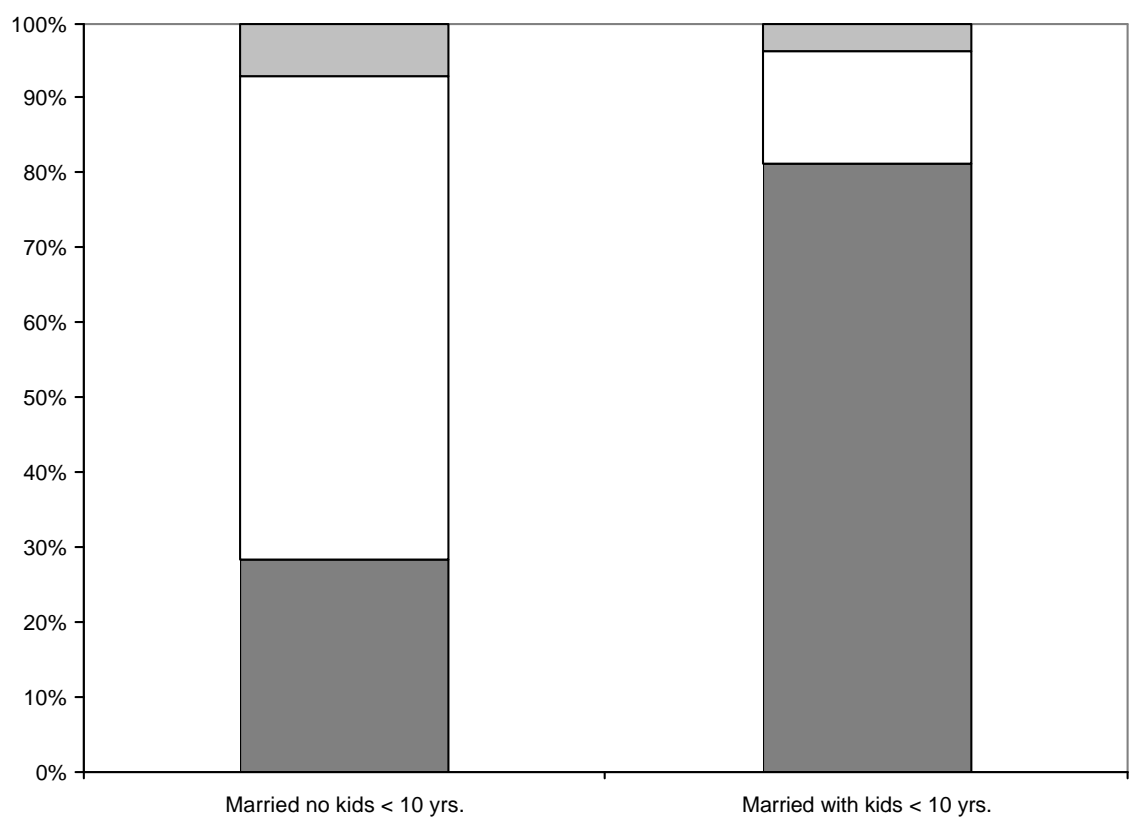

$\square$ Flexible Hours

IIIness / Vacation

$\square$ Other Reasons, e.g.Parental Leave 
Figure 4h: Fraction of Married Women Working at Most 20 hrs./week For Whom Actual Hours are ... Normal Hours, 1992

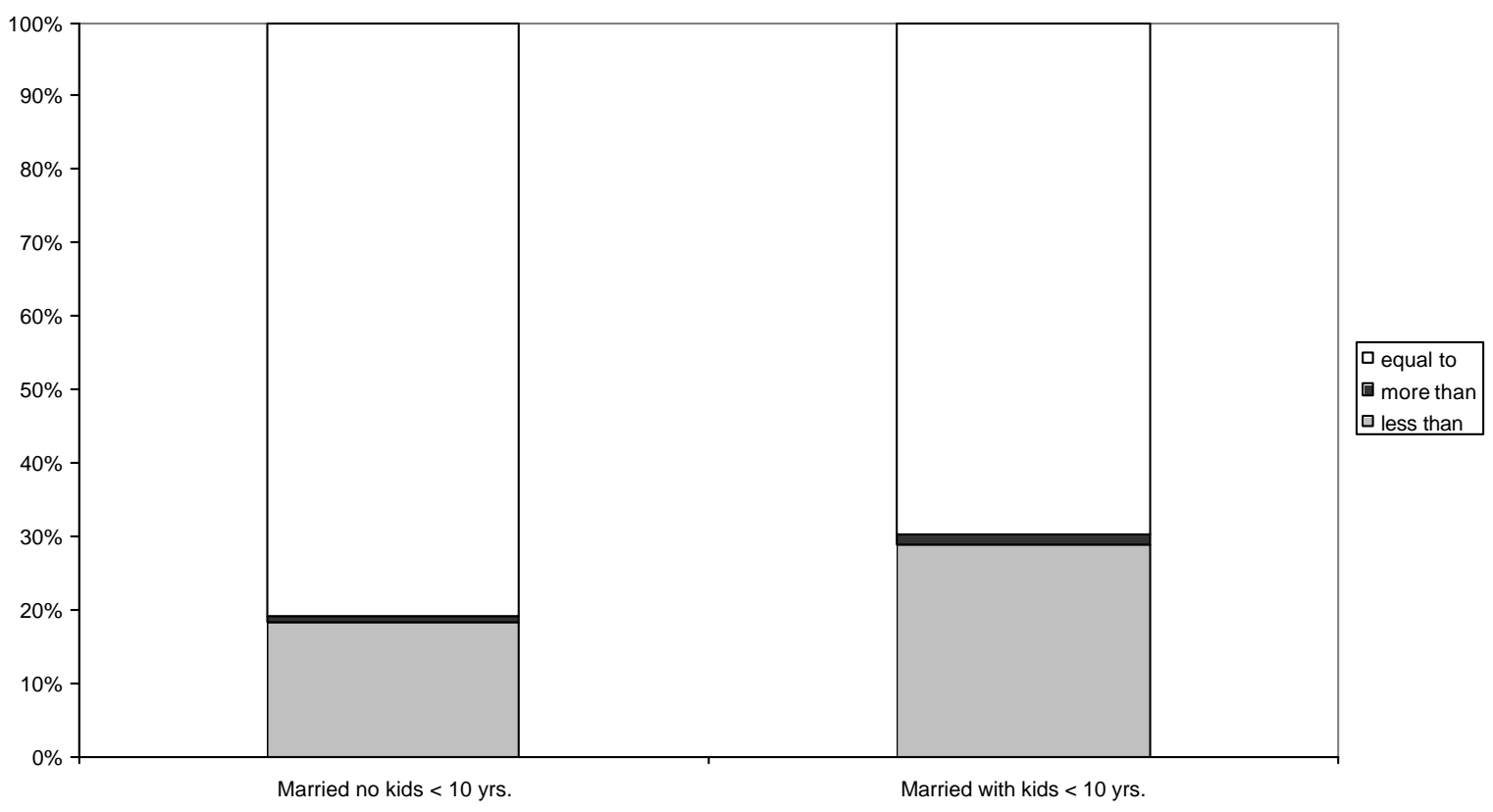

Fraction of Those Women for Whom at Most 20 hrs./week are Less Than Their Normal Hours, Where Deviation is Due To ..., 1992

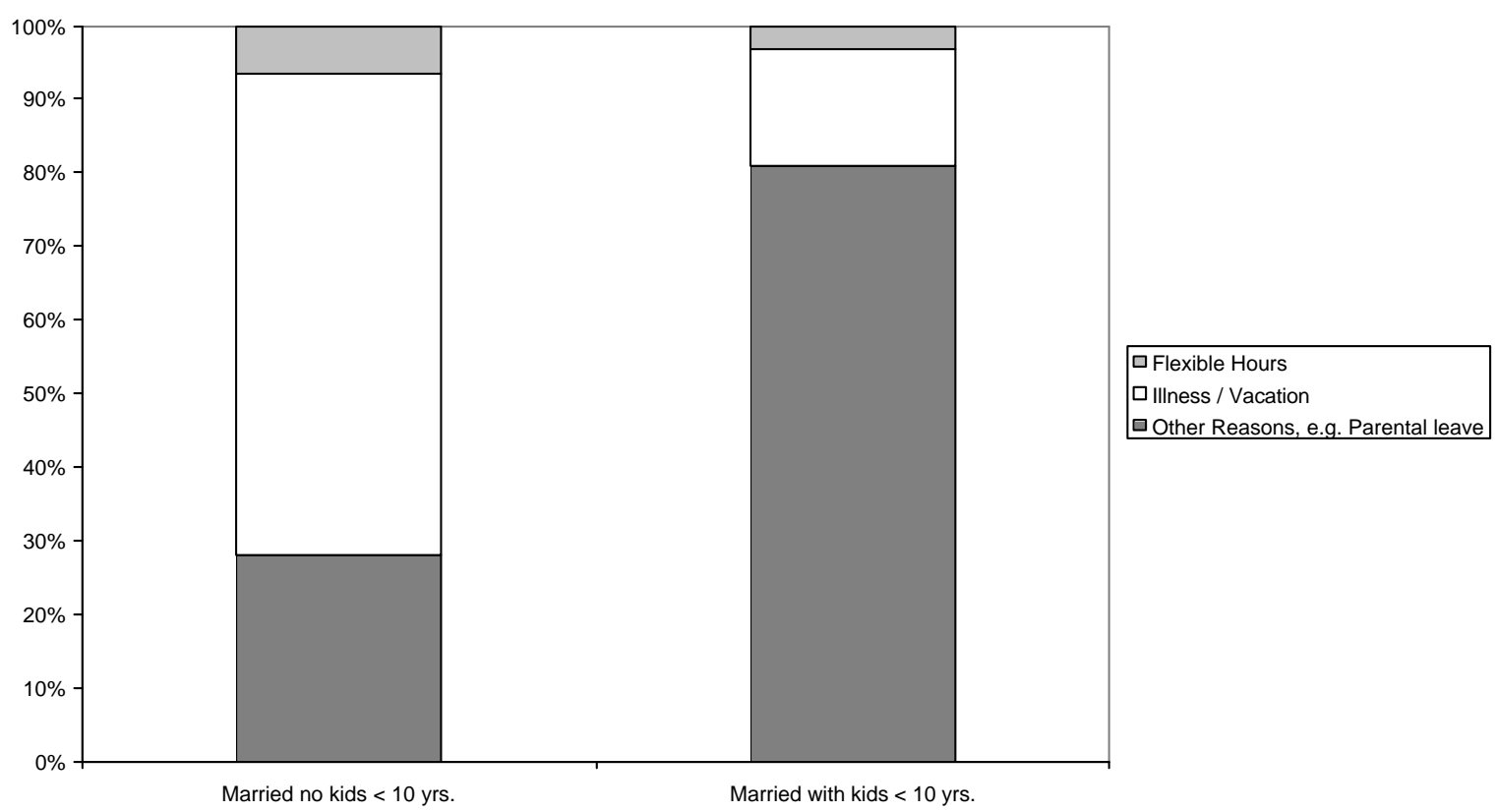

